\title{
The proboscipedia locus of the Antennapedia Complex: a molecular and genetic analysis
}

\author{
Mary Anne Pultz, ${ }^{1}$ Robert J. Diederich, David L. Cribbs, and Thomas C. Kaufman \\ Programs in Genetics and in Molecular, Cellular, and Developmental Biology, and Institute for Molecular and Cellular \\ Biology, Indiana University, Bloomington, Indiana 47405 USA
}

The homeotic proboscipedia (pb) locus of the Antennapedia Complex (ANT-C) directs the differentiation of adult labial and maxillary structures. Loss-of-function $p b$ alleles show a transformation of adult mouth parts to legs and affect maxillary palp morphology. We have identified the $p b$ transcription unit by inducing and analyzing a series of $p b$ null chromosomal breakpoints. In addition, we describe a variegating $p b$ phenotype associated with two rearrangement breakpoints. Having identified the $p b$ locus, we describe the expression of its RNA and protein products. Unlike the other homeotic genes of the ANT-C, $p b$ has no obvious role in embryonic development. Nevertheless, $p b$ protein is detected during embryogenesis in nuclei of the labial and maxillary lobes and in part of the mandibular segment. In this respect, $p b$ expression parallels the early segment-specific expression of neighboring, embryonically essential homeotic genes. Accumulation of $p b$ protein is also detected in mesodermal cells and in a unique subset of nuclei throughout the central nervous system. We also describe a transcription unit very close to $p b$, which is expressed dorsally during embryogenesis in a pattern resembling that of the nearby zygotic lethal zerknüllt (zen) locus. This transcription unit has been shown to contain a homeo box and has been designated $z 2$. Surprisingly, we find that individuals deleted for both the $p b$ and $z 2$ transcription units survive to adulthood and produce normal larval cuticular structures. Thus, $p b$ and $z 2$ show similarities to neighboring ANT-C genes in their expression patterns, yet these similarities are not manifested in comparable loss-of-function embryonic phenotypes.

[Key Words: proboscipedia; z2; Drosophila; homeotic; Antennapedia Complex]

Received November 2, 1987; revised version accepted May 16, 1988.

The unique pattern of each body segment in Drosophila is controlled by homeotic genes. Many of these genes are clustered in two homeotic gene complexes: the Bithorax Complex (BX-C) (Lewis 1978; Sánchez-Herrero et al. 1985) and the Antennapedia Complex (ANT-C) (Denell 1973; Kaufman et al. 1980). The genes of the BX-C direct development of thoracic and abdominal segments, whereas several ANT-C homeotic genes direct development of head and thoracic segments. The roles of homeotic genes have been demonstrated through classical genetic studies: When the function of a homeotic gene is either eliminated or expressed inappropriately, specific segments of the fly develop inappropriate structures characteristic of other segments (for review, see Ouweneel 1976; Gehring and Hiromi 1986; Akam 1987; Scott and Carroll 1987; Kaufman and Olsen 1988).

The ANT-C has been defined genetically as a set of tightly linked genes (Fig. 1A) that control segment identity or other aspects of pattern formation (Duncan and Kaufman 1975; Kaufman et al. 1980; Lewis et al.

'Current address: Department of Biological Sciences, Stanford University, Stanford, California 94305 USA. 1980a,b; Denell et al. 1981; Wakimoto and Kaufman 1981). Five of these genes-Antennapedia (Antp), Sex combs reduced (Scr), Deformed (Dfd), proboscipedia (pb), and labial (lab) - are homeotic in character and play essential roles in adult development (Kaufman 1978; Struhl 1981, 1982; Hazelrigg and Kaufman 1983; Schneuwly and Gehring 1985; Abbott and Kaufman 1986; Merrill et al. 1987, and in prep.). Lack-of-function mutations at all of these homeotic loci, except $p b$, also result in larval segmental transformations and/or gross disruptions in larval head development /Wakimoto and Kaufman 1981; Struhl 1983; Sato et al. 1985; MartinezArias 1986; Merrill et al. 1987, and in prep.; Regulski et al. 1987) In addition to homeotic genes, the ANT-C contains other genes with essential roles in pattern formation, such as the pair-rule fushi tarazu (ftz) gene (Wakimoto et al. 1984), the maternal-effect bicoid (bcd) gene (Frohnhöfer and Nüsslein-Volhard 1986), and the zerknüllt (zen) gene, which is required for dorsal embryonic development (Wakimoto et al. 1984).

The $p b$ locus directs the development of adult labial and maxillary structures (Bridges and Dobzhansky 1933). Complete loss of $p b$ function results in a transformation of the labial palps to prothoracic legs; in addi- 


\section{A. Genetic map of the Antennapedia Complex}

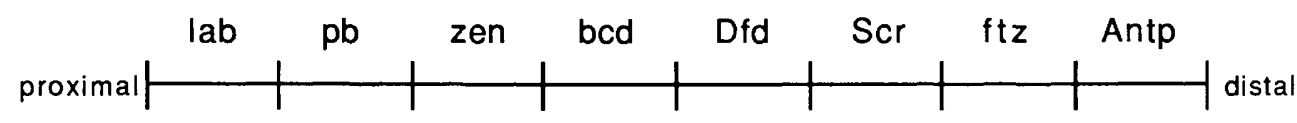

B. Alignment of complementation groups on the molecular map

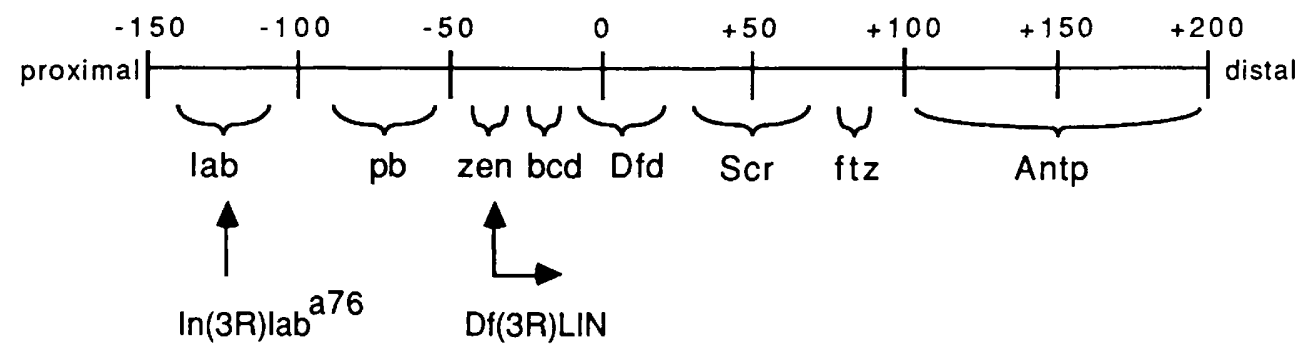

C. Molecular map of the proboscipedia region

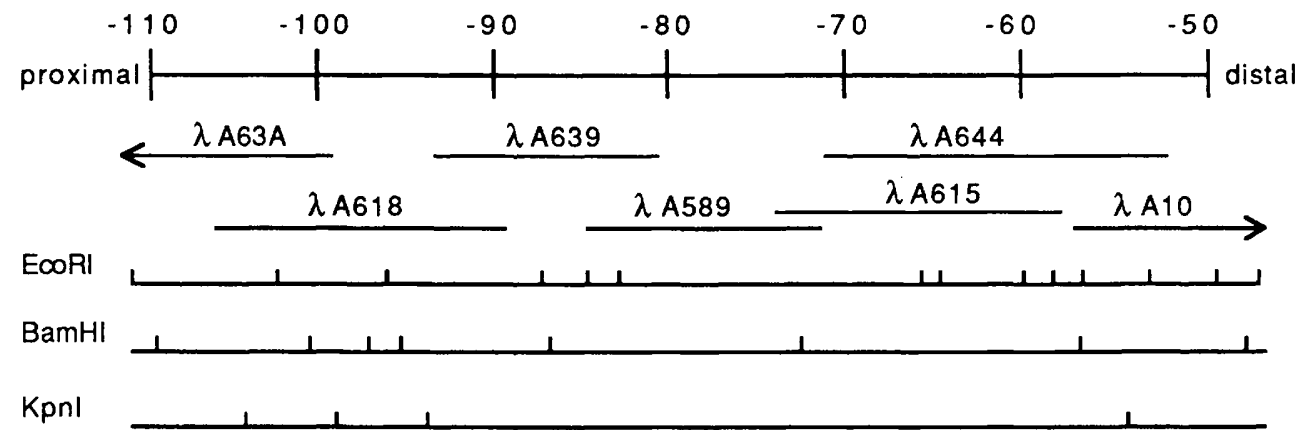

Figure 1. The location of $p b$ within the ANT-C. $(A)$ The genetic map of the ANT-C, showing the position of $p b$. $(B)$ Position of $p b$ on the molecular map of the ANT-C. Coordinates (in kb) are as in Scott et al. (1983). In(3R)lab ${ }^{a 76}$ and $D f(3 R) L I N$ provide proximal and distal genetic limits, respectively, on sequences required for $p b$ function. $(C)$ Restriction map of the $p b$ region, including numerical designations of genomic $\lambda$ phage isolated in the chromosomal walk through this region. Restriction fragments under 0.3 $\mathrm{kb}$ in size are not included. Phage $\lambda 589$ and phage located further distally overlap the restriction map of Scott et al. (1983).

tion, the maxillary palps show a cell-autonomous reduction in size (Kaufman 1978; V. Merrill, pers. comm.). Temperature-sensitive and hypomorphic $p b$ alleles show an alternative transformation of labial palps to antennae (Villee 1944; Kaufman 1978). The $p b$ locus differs from all other ANT-C homeotic loci in that $p b$ function is not obviously required for development of a normal cuticular pattern at the larval stage of the life cycle. Studies of the temperature-sensitive $p b^{1}$ allele have suggested that $p b$ function during late larval and early pupal life plays a critical role in determining adult labial palp identity (Villee 1944).

Figure 1B summarizes the alignment of ANT-C complementation groups on the molecular map of the complex, using the coordinate system of Scott et al. (1983). Molecular analysis has revealed both structural and functional similarities among the loci of the distal ANT-C. Structurally the transcription units of zen, bcd,
$D f d, S c r, f t z$, and Antp each contain variants of a homeo box domain (McGinnis et al. 1984a; Scott and Weiner 1984; Laughon et al. 1985; Doyle et al. 1986; Frigerio et al. 1986). Functionally, each of these loci expresses transcripts and protein products in spatially restricted patterns, which generally reflect localized functions inferred by genetic analysis (Levine et al. 1983; Hafen et al. 1984; Carroll and Scott 1985; Carroll et al. 1986; Doyle et al. 1986; Frigerio et al. 1986; Wirz et al. 1986; M. Seeger and T.C. Kaufman, in prep.). For example, Scr function is required during embryogenesis for development of the labial and first thoracic segments (Wakimoto and Kaufman 1981; Sato et al. 1985); Scr transcripts and protein products accumulate principally in those two segments (Kuroiwa et al. 1985; Levine et al. 1985; Mahaffey and Kaufman 1987; Martinez-Arias et al. 1987; Riley et al. 1987). Similarly, $D f d$ function is required for development of maxillary and mandibular de- 
rivatives (Merrill et al. 1987; Regulski et al. 1987); Dfd transcripts and protein products are expressed primarily in the corresponding embryonic segments /Chadwick and McGinnis 1987; Martinez-Arias et al. 1987; R. Diederich, unpubl.).

We have extended the molecular analysis of the ANT-C to include the $p b$ locus. We have identified the $p b$ transcription unit by analyzing $p b$ null chromosomal rearrangements, and we describe the expression patterns of $p b$ RNA and protein products. In the course of this analysis, we found that an embryonically expressed transcription unit resides in the interval between the designated $p b$ transcription unit and two rearrangement breakpoints associated with $p b$ variegating phenotypes. This neighboring transcription unit does not correspond to any known ANT-C complementation group. We therefore extended our analysis to inquire about the potential function of this additional transcription unit using both molecular and genetic approaches.

\section{Results}

Identification of the $\mathrm{pb}$ locus

Genetically, $p b$ is known to lie between $l a b$ and zen, as determined by recombination mapping (Lewis et al. $1980 \mathrm{a}, \mathrm{b})$. A proximal genetic boundary for $p b$ function is provided by $\operatorname{In}(3 R) l a b^{a 76}$, which complements $p b$ but fails to complement $l a b$. Figure $1 \mathrm{~B}$ shows that the ANT-C breakpoint of this inversion is located within the $l a b$ transcription unit, between coordinates -126 and -119 (R. Diederich et al., in prep.). A distal genetic boundary for $p b$ function is provided by $D f(3 R) L I N$, which complements $p b$ but fails to complement zen and loci distal to zen. The proximal end of this deficiency is located within the zen transcription unit, at approximately -42 (Fig. 1B). The entire $p b$ functional unit therefore must lie between these two breakpoints.

To identify the position of the $p b$ locus more precisely within this $84-\mathrm{kb}$ interval, we have induced a series of $p b$ null rearrangements. The locations of these breakpoints on the molecular map have been determined using the $\lambda$ genomic clones illustrated in Figure 1C. Table 1 summarizes the polytene cytology, molecular mapping methods, parent chromosomes, and sources for all chromosomes discussed in this paper. Breakpoints for all $p b$-associated inversions and deficiency endpoints place $p b$ cytologically at $84 \mathrm{~A} 4,5$. The positions of breakpoints on the molecular map were originally determined using whole-genome Southern blots probed with $\lambda$ genomic clones from this region. Additional methods have been used to refine and verify the locations of many of the breakpoints, as reported in Table 1 and detailed in

Table 1. Chromosomal rearrangements analyzed

\begin{tabular}{|c|c|c|c|c|}
\hline Chromosome & Cytology & $\begin{array}{c}\text { Molecular } \\
\text { mappinga }\end{array}$ & $\begin{array}{c}\text { Parent } \\
\text { chromosome }\end{array}$ & Source \\
\hline \multicolumn{5}{|c|}{$p b$ null rearrangements } \\
\hline $\operatorname{In}(3 R) p b^{\text {win12 }}$ & $84 \mathrm{~A} 4,5-87 \mathrm{AB}$ & $\mathrm{A}, \mathrm{B}$ & Ki roe $p^{p}$ & Kaufman \\
\hline $\operatorname{In}(3 L R) p b^{\text {lose1 }}$ & $84 \mathrm{~A} 4,5-66 \mathrm{~B}$ & A,B & $T a^{L}\left(\right.$ Ki roe $\left.p^{p}\right)$ & Kaufman \\
\hline $\operatorname{In}(3 R) p b^{\operatorname{map} 9}$ & $84 \mathrm{~A} 4,5-84 \mathrm{D}$ & A & Ore $\mathrm{R}$ & Pultz \\
\hline $\operatorname{In}(3 R) p b^{\operatorname{map} 12}$ & $84 \mathrm{~A} 4,5-85 \mathrm{D}$ & A & $P\left(S 38 r y^{+}\right) r y^{506}$ & Pultz \\
\hline $\operatorname{In}(3 R) p b^{\operatorname{map} 10}$ & $84 \mathrm{~A} 4,5-80,81^{\mathrm{b}}$ & A,B & Ki roe $p^{p}$ & Pultz \\
\hline \multicolumn{5}{|c|}{$p b$ null molecular deletions } \\
\hline$p b^{\text {map 13 }}$ & normal, pseudopoint & $\mathrm{A}, \mathrm{B}, \mathrm{Cl}$ & $P\left(\right.$ S38ry $\left.{ }^{+}\right) \mathrm{ry}^{506}$ & Pultz \\
\hline$p b^{\text {map } 8}$ & multiply rearranged & $\mathrm{A}, \mathrm{B}, \mathrm{Cl}, \mathrm{C} 2$ & Ore $\mathbf{R}$ & Pultz \\
\hline \multicolumn{5}{|c|}{$p b$ null cytological deficiencies } \\
\hline$D f(3 R) M A P 2$ & $84 \mathrm{Al}, 2-84 \mathrm{~A} 4,5$ & $\mathrm{~A}, \mathrm{~B}, \mathrm{C} 1, \mathrm{C} 2$ & Ore $\mathrm{R}$ & Pultz \\
\hline$D f(3 R) S c x^{W+R X 2}$ & $84 \mathrm{~A} 4,5-84 \mathrm{Cl}, 2$ & A,B,D & $S c x^{w}($ red e) & Hazelriggc \\
\hline$D f(3 R) W I N 3$ & $84 \mathrm{~A} 4,5-84 \mathrm{Cl}, 2$ & $\mathrm{~A}, \mathrm{~B}, \mathrm{C} 2$ & Ki roe $p^{p}$ & Kaufman \\
\hline$D f(3 R) X 2$ & $84 \mathrm{~A} 4,5-84 \mathrm{~B} 1,2$ & A & ri $p^{p}$ & Kaufman \\
\hline$D f(3 R) W I N 1$ & $84 \mathrm{~A} 4,5-84 \mathrm{~B} 1,2$ & A,B & Ki roe $p^{p}$ & Kaufman \\
\hline \multicolumn{5}{|c|}{$p b$ variegating chromosomes } \\
\hline $\operatorname{In}(3 L R) M A P 17$ & $84 \mathrm{~A} 4,5-80,81^{\mathrm{b}}$ & $\mathrm{A}, \mathrm{B}, \mathrm{E}$ & $p^{p}$ & Pultz \\
\hline$D f(3 R) S C B^{X L 2}$ & $84 \mathrm{~A} 4,5-84 \mathrm{~B} 1,2$ & $\mathrm{~A}, \mathrm{~B}, \mathrm{Cl}$ & & Jürgens $^{d}$ \\
\hline \multicolumn{5}{|l|}{ Other chromosomes } \\
\hline $\ln (3 R) 1 a b^{a 76}$ & $84 \mathrm{~A}-84 \mathrm{E}$ & A & red $e$ & Abbott ${ }^{e}$ \\
\hline$D f(3 R) L I N$ & $84 \mathrm{~A} 4,5-84 \mathrm{~B}$ & A,B & & Frohnhöfer ${ }^{d}$ \\
\hline
\end{tabular}

All lesions were induced with X-rays except $D f(3 R) L I N$, which was induced with ethylmethane sulfonate (EMS).

a Molecular mapping methods A-E are explained in Materials and methods.

b Segregation analysis confirms that the heterochromatic break is on the third chromosome.

c Hazelrigg and Kaufman (1983).

d Provided by C. Nüsslein-Volhard.

e Recovery of mutant chromosome: Abbott (1984). Cytology: T. Kaufman. 
Pultz et al.

Materials and methods. We have used the term 'deletion' to describe two chromosomes that are not identifiable as deficiencies cytologically or genetically but have been shown by molecular analysis to have sequences deleted.

As shown in Figure 2A, five $p b$ null mutations are associated with inversion breakpoints, defining a 29 -kb region that cannot be interrupted without totally abolishing $p b$ function. The molecular lesions for these rearrangements fall in the interval from -83 to -54 . In addition, Figure $2 \mathrm{~B}$ shows that the cytologically normal $p b^{\text {map } 13}$ null allele is associated with a deletion of $\sim 5 \mathrm{~kb}$, between -59 and -54 , implying that the integrity of sequences within this $5-\mathrm{kb}$ interval is essential for $p b$ function. Together, these lesions define the minimum extent of the $p b$ locus.

A larger deletion is associated with the $p b^{\text {map8 }}$ chromosome. This deletion defines a $60-\mathrm{kb}$ interval, from approximately -110 to -50 , which can be deleted without inactivating $l a b$, zen, or any identified genetic functions other than $p b$.

We have also recovered several cytologically visible deficiencies with end points in the $p b$ region; these are illustrated in Figure 2C. The $D f(3 R) M A P 2$ chromosome

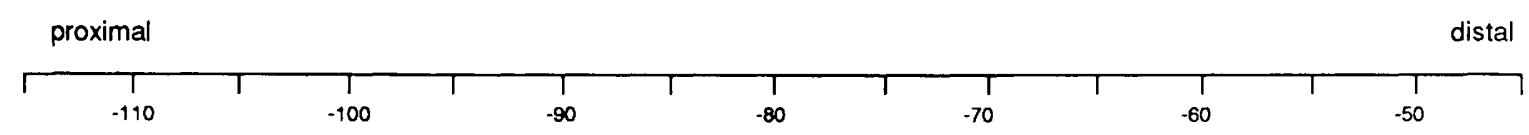

A. $p b$ null inversions

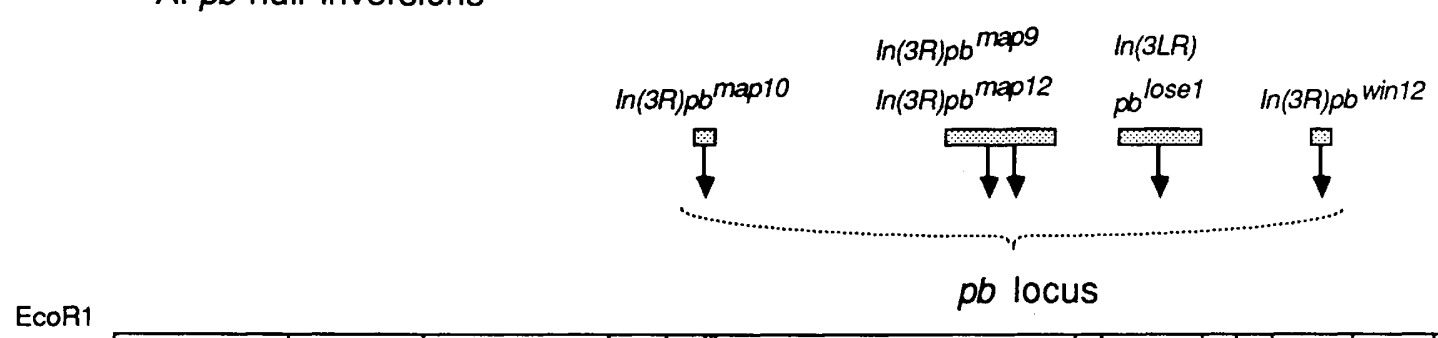

B. pb null molecular deletions

$p b^{\text {map } 13}$ deletion

$p b^{\text {maps }}$ deletion $\left(a b^{+}, p b^{-}, z^{+} n^{+}\right)$

C. pb null cytological deficiencies

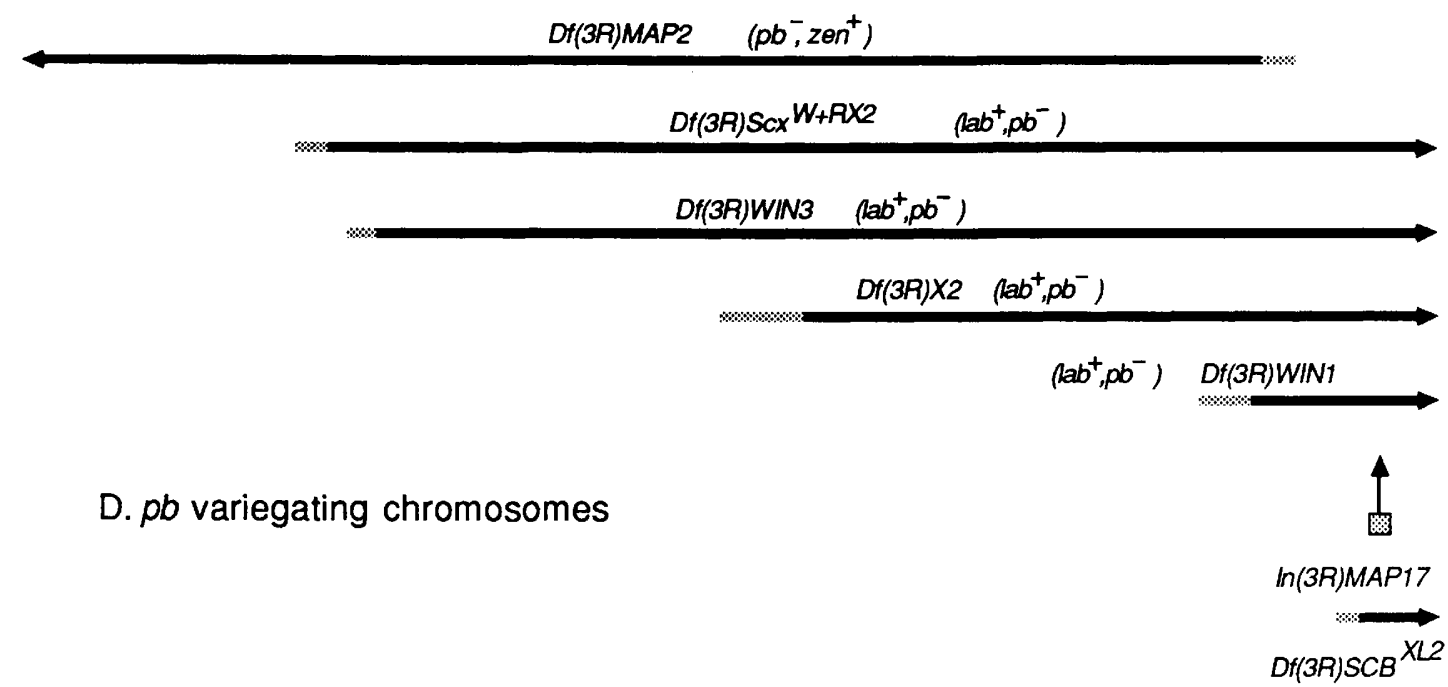

Figure 2. The positions of chromosomal rearrangements that define the $p b$ locus and the $p b$ region. $(A)$ Five $p b$ null inversions define the minimum size of the $p b$ locus. $(B)$ Deletions detected by molecular analysis of mutant chromosomes, including the $p b^{\text {map } 8}$ deletion and the $p b^{\text {map } 13}$ deletion. $(C)$ The positions of $p b$ null deficiency end points located within the $p b$ region. $(D)$ The locations of $p b$ variegating breakpoints, which map distal to the $p b$ null breakpoints. Stippling indicates the degree of uncertainty of breakpoint locations. For further description of these chromosomes, see Table 1. 
complements zen and fails to complement $p b, 1 a b$, and loci proximal to lab. The distal end point of $D f(3 R) M A P 2$ is located at about -54 . Several deficiency chromosomes complement lab but fail to complement $p b$ and loci distal to $p b$. These include $D f(3 R) S c X^{W+R X 2}$, $D f(3 R) W I N 3, D f(3 R) X 2$, and $D f(3 R) W I N 1$. Each of these chromosomes allows survival to adulthood when heterozygous with $D f(3 R) M A P 2$, and each combination produces phenotypically $p b^{-}$adults. These results are consistent with the analysis of the rearrangements described above, because each deficiency combination deletes at least part of the interval defined by $p b$ null inversion breakpoints as essential for $p b$ function. In addition, examination of cuticle preparations from genetically marked animals bearing overlapping deficiency combinations revealed no defects in larval cuticular structures (see Materials and methods).

\section{Two rearrangements have a $\mathrm{pb}$ variegating phenotype}

In addition to mapping chromosomal rearrangements that complement or completely fail to complement $p b$, we have also mapped lesions for two chromosomal rearrangements, $\operatorname{In}(3 R) M A P 17$ and $D f(3 R) S C B^{X L 2}$, which fail to complement $p b$ in a partial and variegating fashion (Fig. 2D). Figure 3 contrasts the previously described $p b$ null and $p b$ hypomorphic phenotypes (Kaufman 1978) with the phenotypes of the $p b$ variegating chromosomes. The $p b$ null phenotype is exemplified by a $D f(3 R) M A P 2 /$ $D f(3 R)$ WIN3 female, which is deleted for the $p b$ locus (Fig. 3B): the labial palps are extensively transformed to prothoracic legs, whereas the maxillary palps are small and malformed relative to those of wild-type individuals (cf. Fig. 3A and B). The ectopic legs in $p b$ null individuals are of prothoracic identity, shown by the presence of sex combs in a $p b^{-}$male (Fig. 3C). Figure 3, D and $\mathrm{E}$, illustrate the range of phenotypes obtained with a $p b$ hypomorphic allele, $p b^{4}$, in heterozygous combination with $p b^{-}$deficiencies. Transformations range from a predominantly antennal morphology (Fig. 3D, right), to a mixture of antenna-like and leg-like characteristics, illustrated by the presence of a claw on the ectopic aristalike appendage in Figure 3E. In contrast, the labial palp transformations of $p b$ variegating individuals consist of limited patches of leg-like tissue, illustrated by claws emerging from the partially transformed labial palps of an $\operatorname{In}(3 R) M A P 17 / p b^{-}$individual (Fig. 3F) and by a similar transformation in a $D f(3 R) S C B^{X L 2} / p b^{-}$individual (Fig. 3G). The labial palps of individuals carrying $p b$ variegating chromosomes do not display antenna-like transformations, except when a $p b$ variegating chromosome is in heterozygous combination with a hypomorphic $p b$ allele.

One of the $p b$ variegating chromosomes, In( $3 R) M A P 17$, inverts sequences from -48 on our map into heterochromatin. At $22^{\circ} \mathrm{C}, \operatorname{In}(3 R) M A P 17 / p b^{-}$individuals have a highly penetrant reduction of maxillary palps similar to the maxillary palp phenotype observed in $p b$ null flies, as well as a less penetrant labial palp phenotype. Many of the affected individuals show a phe- notype like that illustrated in Figure 3F, with claws emerging from the labial palps, whereas other individuals have small patches of more proximal leg tissue, including sex combs, emerging from the labial palps. These transformations resemble patches of transformed tissue observed in mitotic recombination experiments using $p b$ null alleles (V. Merrill, unpubl.). Thus, the In(3R)MAP17/p $b^{-}$phenotype most likely represents a complete inactivation of $p b$ function in a clone of cells, as expected for a typical V-type position effect (Spofford 1976). In(3R)MAP17/pb- individuals also show a temperature sensitivity typical for heterochromatic variegating position effects: The variegating phenotype is enhanced at $18^{\circ} \mathrm{C}$ and suppressed at $29^{\circ} \mathrm{C}$.

A similar phenotype is also observed with $D f(3 R) S C B^{X L 2}$, which is apparently an entirely euchromatic deficiency with a proximal breakpoint at about -51 (this chromosome and $D f(3 R) L I N$ were kindly provided by Dr. C. Nüsslein-Volhard). $D f(3 R) S C B^{X L 2} / p b^{-}$ flies show a completely penetrant maxillary palp phenotype, as well as a labial palp phenotype (Fig. 3G) similar to that of $\operatorname{In}(3 R) M A P 17 / p^{-}$flies, although the labial palp phenotype is more penetrant and often transforms larger patches of tissue than is typical for $\operatorname{In}(3 R) M A P 17 /$ $p b^{-}$flies. In addition, we have not detected an effect of temperature on the $D f(3 R) S C B^{X L 2} / p b^{-}$phenotype.

Both $p b$ variegating rearrangements map in the interval between the most distal $p b$ null inversion breakpoints at approximately -54 and the $p b^{+} D f(3 R) L I N$ breakpoint at -42 . The $p b$ transcriptional analysis described below indicates that these breakpoints lie $5^{\prime}$ to the $p b$ transcription unit.

\section{The $\mathrm{pb}$ transcription unit}

The transcriptional activity of the $p b$ region was first characterized by probing developmental Northern blots with individual genomic $\lambda$ phage encompassing the chromosomal walk through this region. This preliminary analysis divided the region into three transcribed intervals (Fig. 4A). First, sequences between -110 and -90 detected a series of small RNAs, ranging from 0.7 to $1.1 \mathrm{~kb}$ in size, expressed during late embryonic, larval, and pupal stages of development. Several cDNA clones corresponding to this interval were analyzed by restriction mapping and by preliminary DNA sequencing. This analysis indicated the presence of a family of genes that are structurally related to one another (Kaufman and Olsen 1988; Pultz 1988). The proximal portion of this transcript cluster was isolated independently in a screen for genes that have a profile of ecdysone-dependent expression similar to that of pupal cuticle protein genes (Fechtel et al. 1988). Because this cluster of transcripts maps entirely outside of the interval defined by the $p b$ null breakpoints, we concluded that they were unlikely to be functionally related to $p b$, and they will not be considered further here. Second, sequences between -90 and -54 detected a 4.3-kb RNA size class that is expressed in embryos, larvae, and pupae. This RNA is implicated as the transcript of the $p b$ locus, as described 
Pultz et al.
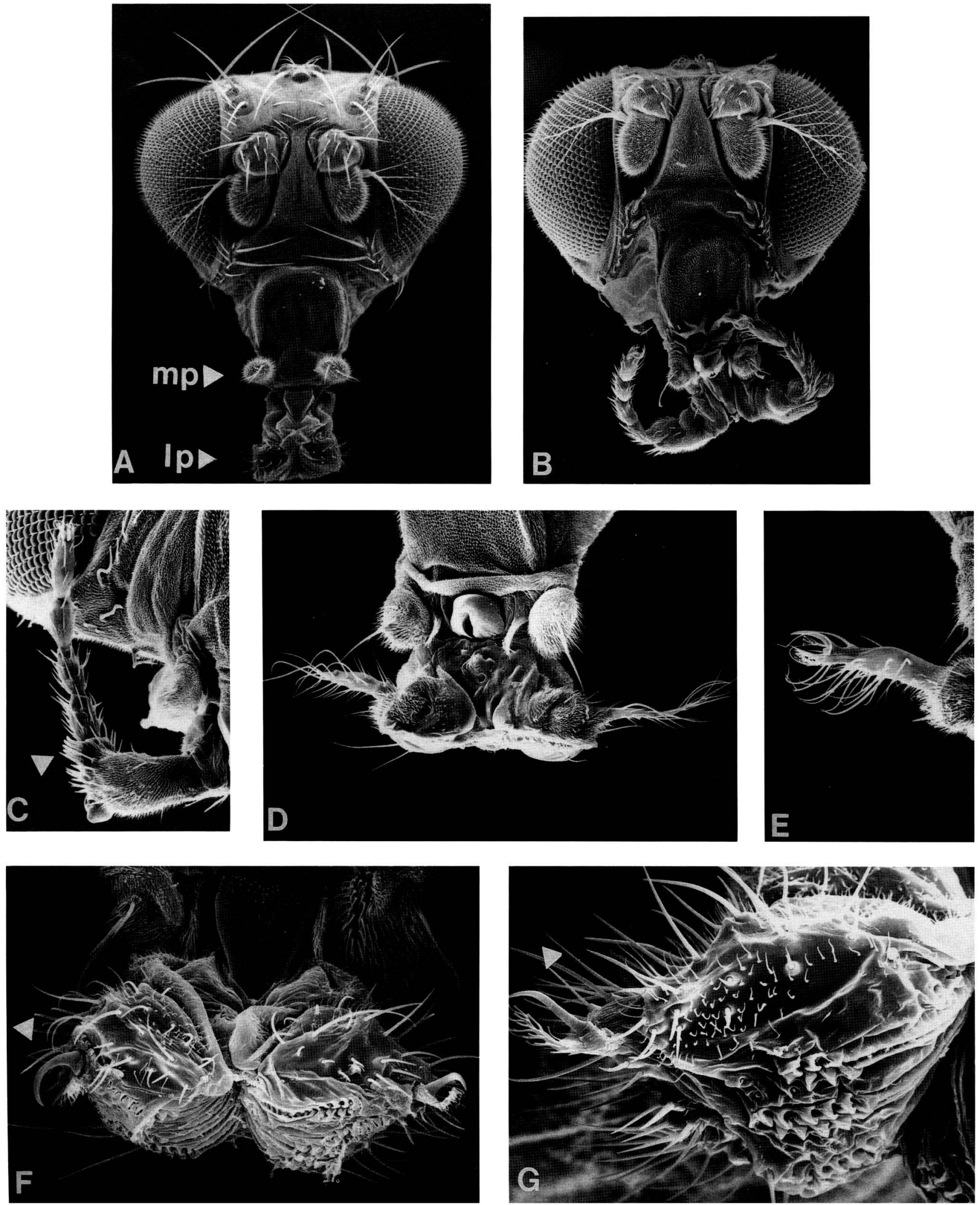

Figure 3. (See facing page for legend.) 
below. Finally, sequences between -54 and -50 hybridized to a 1.1-kb RNA size class expressed in early embryos, as described in the next section.

To localize the sequences encoding the 4.3-kb RNA size class, Northern blot strips of embryonic RNA were probed with subcloned genomic restriction fragments spanning the interval from -95 to -50 . The $4.3-\mathrm{kb}$ RNA is detected by genomic fragments from both ends of a $34-\mathrm{kb}$ interval, from -88 to -83 and from -58 to -54 (fragments A-D, Fig. 4A). The genomic sequences that hybridize to the 4.3-kb RNA correspond well to the sequences defined genetically as essential for $p b$ function. The $34-\mathrm{kb}$ interval defined by this Northern analysis contains the $29-\mathrm{kb}$ interval that was defined genetically as the minimum size of the $p b$ locus. In addition, transcribed genomic sequences at the distal end of this interval, from -58 to -54 , map within the $5-\mathrm{kb} p b^{\text {map } 13}$ deletion (Fig. 4A). On this basis, we have designated this 4.3-kb RNA size class as the $p b$ transcript. The direction of transcription of the $4.3-\mathrm{kb} p b$ RNA is from distal to proximal on the chromosome and was determined using single-stranded probes from fragments $A, B$, and D (Fig. 4A), as described in Materials and methods.

The simplest interpretation of the combined genetic and Northern data is that the $4.3-\mathrm{kb} p b$ RNA is spliced from a primary transcript that spans the interval from approximately -54 to -88 . If this hypothesis is correct, $p b$ null breakpoints located at one end of the $p b$ locus should eliminate the 4.3-kb RNA recognized by genomic fragments from the other end. To test this prediction, RNA was prepared from genetically marked $D f(3 R) W I N 1 / D f(3 R) M A P 2$ pupae. $D f(3 R) M A P 2$ deletes the proximal $\left(3^{\prime}\right)$ component of the $p b$ locus, whereas $D f(3 R)$ WIN1 deletes only the distal $\left(5^{\prime}\right) 2-4 \mathrm{~kb}$ of the $p b$ locus; thus, the proximal part of the $p b$ locus is present in one copy in the deficiency bearing animals. A Northern blot of RNA from wild-type pupae and from the deficiency bearing pupae was probed with the sequences between -88 and -87 (the proximal $1.0 \mathrm{~kb}$ of fragment A, Fig. 4A); the results demonstrate that the 4.3-kb RNA is present in wild-type pupae (Fig. 4B, lane 1) but absent in the deficiency-bearing pupae (Fig. 4B, lane 2). These results are consistent with the interpretation that sequences from the proximal and distal portions of the $p b$ locus hybridize to the same $4.3-\mathrm{kb}$ transcript.

The temporal profile of $p b$ expression during development was determined by preparing poly $(\mathrm{A})^{+}$RNA from developmentally staged embryos, larvae, pupae, and adults; a Northern blot containing these RNAs was hybridized with a genomic fragment from the distal $\left(5^{\prime}\right)$ end of the $p b$ locus (fragment E, Fig. 4A; see also Fig. $5 \mathrm{~A})$. Figure $4 \mathrm{C}$ illustrates that the $4.3-\mathrm{kb} p b$ transcript is first detected at $2-4 \mathrm{hr}$ of embryogenesis, and maximal accumulation is observed at $6-8 \mathrm{hr}$ of embryogenesis. The abundance of the $p b$ transcript diminishes toward the end of embryogenesis. During the larval period, $p b$ expression is most evident in second instar larvae. Another peak in $p b$ transcript abundance is seen during the second $12 \mathrm{hr}$ of pupal development, when a minor band of $\sim 4 \mathrm{~kb}$ is also detected. By the end of the pupal period, accumulation of the $p b$ transcript has diminished again, and the $p b$ transcript is not detected in adults.

\section{The embryonically expressed transcription unit distal to $\mathrm{pb}$}

Immediately distal to the $p b$ transcription unit, between -54 and -51 on our map, there is an early embryonic transcription unit that produces a $1.1-\mathrm{kb}$ transcript. Because of the close proximity of this transcription unit to the $p b$ transcription unit, it was important to determine more precisely the relative locations of the genomic sequences encoding these two RNAs. Data presented in Figure 4A show that no hybridization to the 1.1-kb RNA is detected with sequences proximal to -54 . Furthermore, Figure $4 \mathrm{C}$ shows that the 1.1-kb RNA is not detected with sequences extending further distally to the PstI site at -53.3 (fragment E, Figs. $4 \mathrm{~A}$ and $5 \mathrm{~A}$ ). However, Figure 5 shows that sequences extending from -54 to -52 do hybridize to the 1.1-kb RNA (fragments $F$ and $\mathrm{G}$, Fig. $5 \mathrm{~A}, \mathrm{~B})$. These sequences do not detect the $4.3-\mathrm{kb}$ $p b$ RNA. Neither transcript is detected with sequences distal to -52 (data not shown). These results indicate that all hybridization to the $1.1-\mathrm{kb}$ embryonic transcript is detected with sequences located distal to the PstI site at -53.3 . Moreover, all detectable hybridization to the $p b$ RNA is located proximal to the KpnI site at -54 . Thus, there is apparently no overlap between the genomic sequences that hybridize to these two transcripts. The direction of transcription of the 1.1-kb RNA is the same as that for the 4.3-kb $p b$ RNA, from distal to proximal on the chromosome, and was determined using single-stranded RNA probes (see Materials and methods). Figure 5C shows that a peak of accumulation of this transcript is observed at 2-4 hr of development, with lesser amounts at $0-2$ and 4-6 hr. No significant accumulation of the 1.1-kb RNA is observed at postembryonic stages of the life cycle (data not shown).

The position of the early embryonic transcription unit relative to the $p b$-related breakpoints is enigmatic. As illustrated in Figure 5A, this transcription unit is located

Figure 3. Scanning electron micrographs of $p b$ phenotypes. $(A)$ Head of an OreR wild-type individual; $(\mathrm{mp})$ maxillary palp; (lp) labial palp. $(B)$ Head of a $D f(3 R) M A P 2 / D f(3 R) W I N 3, K i$ roe $p^{p}$ female. This genotype is completely deleted for the $p b$ locus. $(C)$ Transformed leg of a $D f(3 R) M A P 2 / D f(3 R) W I N 1, K i$ roe $p^{p}$ male; arrowhead indicates sexcomb, diagnostic of transformation to prothoracic leg. $(D)$ Hypomorphic labial-to-antennal transformation of a $K i \mathrm{pb}^{4} \mathrm{p}^{p / S c X^{W+R X}}$ individual. $(E)$ Labial-to-mixed-antennal/leg transformation of a $K i p b^{4} p^{p / D f}(3 R)$ WIN 3, Ki roe $p^{p}$ individual. $(F)$ Partial labial-to-leg transformation of a $p b$ variegating $\operatorname{In}(3 R) M A P 17 /$ $D f(3 R) W I N 1, K i$ roe $p^{p}$ individual. Arrowhead indicates claw. (G) Partial labial-to-leg transformation of a $p b$ variegating $D f(3 R) S C B^{X L 2} / p b^{\text {map8 }}$ individual. Arrowhead indicates claw; note similarity to $E$. 
Pultz et al.

A. proximal

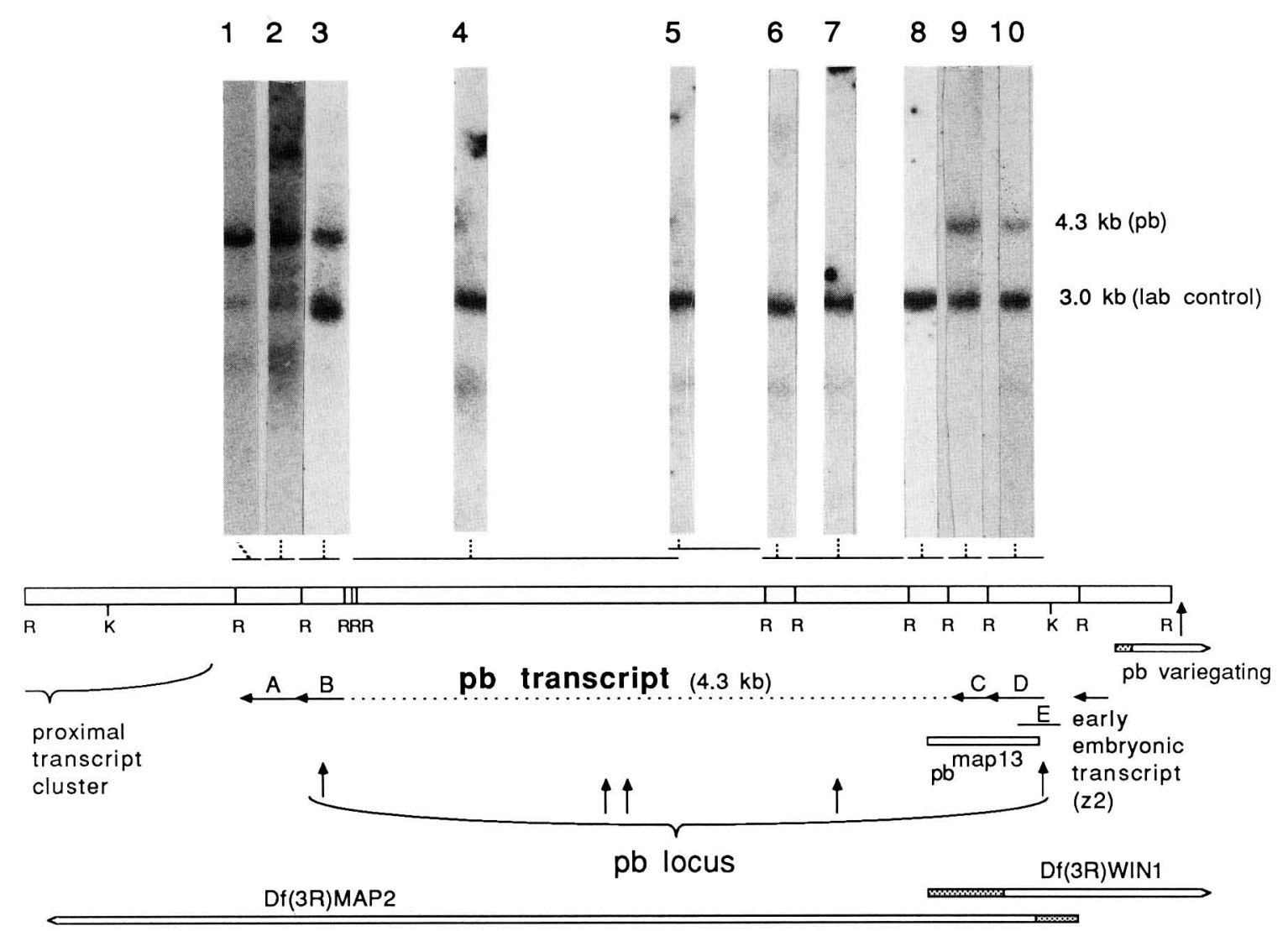

B.

C.

embryonic larval pupal

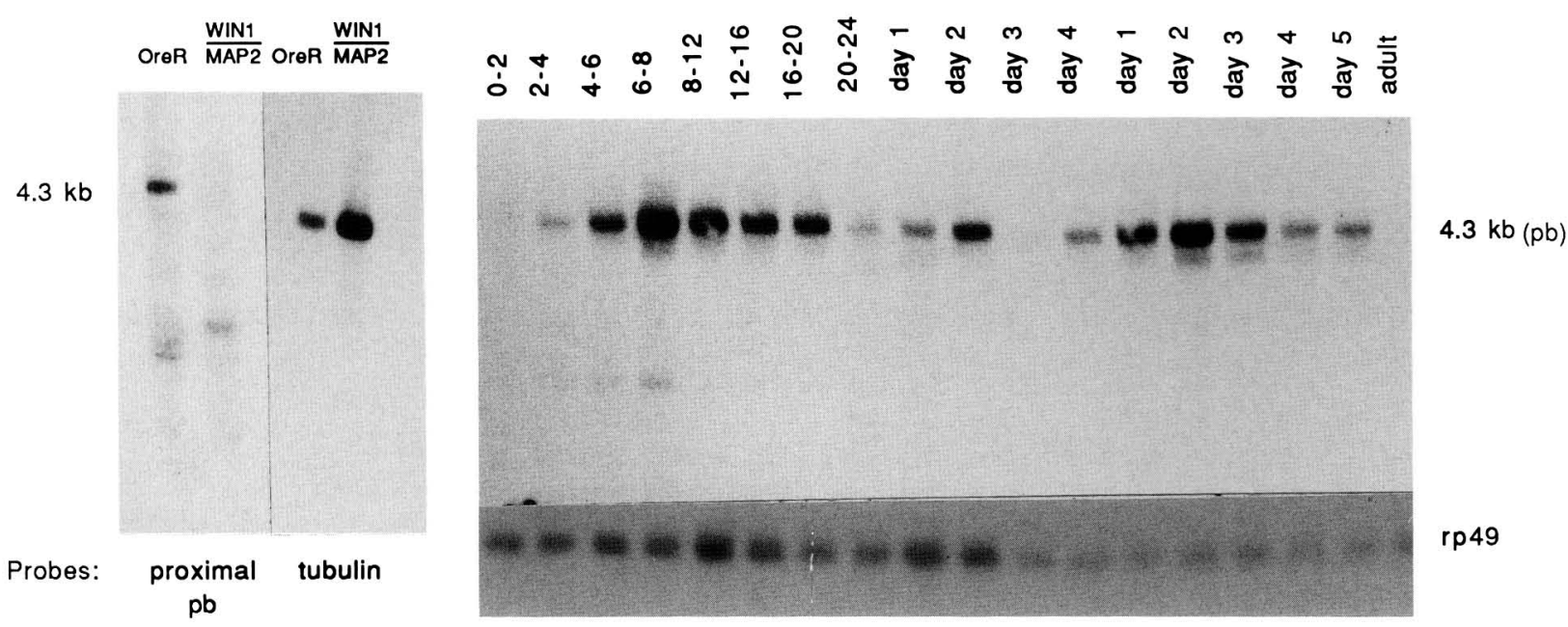

Figure 4. (See facing page for legend.) 
in the interval between the most distal $p b$ null inversion breakpoint and the most proximal $p b$ variegating breakpoint. In addition, the 1.1-kb embryonic transcription unit is located within the $p b^{\text {map8 }}$ deletion and thus can be deleted with $p b$, without revealing any phenotypic consequences other than the $p b$ null phenotype. The location of the early embryonic transcription unit relative to existing $p b$ region breakpoints leaves an open question: Does this transcription unit have a $p b$-related function? To determine whether the early embryonic transcription unit is expressed in a pattern that would suggest a $p b$-related function, the spatial distribution of the 1.1-kb RNA was examined by in situ hybridization, using genomic sequences from -52.7 to -52 (fragment G, Fig. 5A).

Figure 6 illustrates the spatial expression pattern of the $1.1-\mathrm{kb}$ early embryonic RNA. During the late cleavage stages and before cellular blastoderm, the early embryonic RNA is localized along the dorsal surface of the embryo and extends ventrally around the anterior and posterior ends (Fig. 6A). The localization of this RNA then becomes more restricted along the anteriorposterior axis and is limited to the region of the dorsal folds as gastrulation proceeds (Fig. 6B). A similar spatial restriction also occurs in the lateral distribution of transcripts. The cross-section in Figure 6C illustrates that transcripts are distributed in a precellular embryo over $\sim 30 \%$ of the circumference, but by the time cellularization takes place (Fig. 6D), transcript distribution has narrowed markedly, to $\sim 10 \%$ of the circumference of the embryo. In later embryos, transcript distribution remains limited to a narrow dorsal strip as gastrulation proceeds (Fig. 6E,F). As the germ band extends, transcript accumulation is concentrated in the region of the dorsal folds, as seen in two serial sections of the same embryo (Fig. 6G,H). The spatial expression pattern of this early transcription unit is strikingly similar to that observed for the neighboring zen locus (Doyle et al. 1986; M. Seeger, unpubl.) and has been designated $z 2$ (Rushlow et al. 1987).

\section{Expression of $\mathrm{pb}$ protein during embryogenesis}

The characterization of $p b$ transcript accumulation described above showed that embryogenesis is a major period of $p b$ expression. Given the lack of any known $p b$ embryonic function, this raised the question of whether embryonic $p b$ expression might represent gratuitous accumulation of transcripts or whether the transcripts actually function to direct the synthesis of $p b$ protein. This question was pursued using polyclonal rabbit antibodies raised against a $\beta$-galactosidase fusion protein containing a segment of genomic protein-coding $p b$ sequences (see Materials and methods).

Localized staining was observed when embryos were incubated with antibodies raised against the fusion protein (see Materials and methods). First, it was important to determine whether all aspects of the putative anti- $p b$ staining are eliminated when $p b$ function is abolished, to address the possibility that the observed staining patterns might be due to spurious antibody reactivity. Embryos from a balanced stock of the amorphic $p b^{5}$ allele were analyzed; as expected, $\sim 25 \%$ of the embryos from this stock failed to exhibit any of the anti-pb staining patterns described below, whereas all embryos of a similarly balanced $p b^{+}$stock were stained. Therefore, the antibody staining is dependent on $p b$-gene function, and indicates the presence of $p b$ protein (or the presence of a gene product that is dependent on $p b$ function).

Expression of $p b$ protein is observed throughout much of embryogenesis; the approximate ages of the embryos

Figure 4. Transcription of $p b$. (A) An $E c o R I(R)$ plus $K p n I(K)$ restriction map of the -50 to -90 interval; horizontal arrows and letters A-D indicate EcoRI or EcoRI-KpnI restriction fragments, which hybridize to the 4.3-kb pb RNA. Shown above the restriction map are Northern blot lanes of embryonic poly $(\mathrm{A}))^{+}$RNA $(10 \mu \mathrm{g} / \mathrm{lane})$ that have been probed with subcloned genomic fragments spanning the interval from -88 to -54 (results of Northern blot analysis of the -55 to -50 interval are presented in Fig. 5). All probes contained approximately equal $\mathrm{cpm} / \mu \mathrm{g}$, and each probe was mixed with an aliquot of a probe that recognizes the 3.0-kb lab message (R. Diederich et al., in prep.) to monitor the presence of equal amounts of RNA in each lane. All lanes contain RNA from 4- to 8-hr old embryos, except lanes 3 and 10, which contain 8- to 12-hr embryonic RNA. The probes used were the proximal $1.0 \mathrm{~kb}$ (EcoRI-PstI) of fragment A (2.7 kb EcoRI) (1), the distal $1.7 \mathrm{~kb}$ (PstI-EcoRI) of fragment A (2), fragment B (1.7 kb EcoRI) (3), a 13-kb fragment spanning from a genomic EcoRI site at about -83 to a phage EcoRI linker site, including sequences to $\sim-70$ (4), a $4.7-\mathrm{kb} E c o \mathrm{RI}$ fragment that spans from a phage linker site to the genomic EcoRI site at $\sim-66$, including sequences from $\sim-71$ to $-66(5)$, the $1.3-\mathrm{kb}$ EcoRI fragment (6), the 4.7-kb genomic EcoRI fragment (7), the proximal 1.6-kb EcoRI fragment (8), fragment C, the distal 1.6-kb EcoRI fragment $(9)$, and fragment D, a 2.6-kb EcoRI-KpnI fragment (10). Fragments proximal and distal to these 10 probes did not yield a detectable signal for the 4.3-kb RNA. Sequences between -87 and -85 hybridize to a background of other RNAs in addition to the 4.3-kb RNA; this is presumably due to the presence of repetitive CAX sequences (D. Cribbs, unpubl.); such repetitive ' $M$ ' or 'opa' sequences are typically associated with homeotic genes (McGinnis et al. 1984b; Regulski et al. 1985; Wharton et al. 1985). A minor band of $\sim 1.9 \mathrm{~kb}$ is not believed to represent specific hybridization (see Materials and methods). The positions of molecular lesions, which provide genetic landmarks for the $p b$ locus, are shown as vertical arrows ( $p b$ null inversion breakpoints) and as a short open bar (the $p b^{\text {map13 }}$ deletion). Long open bars indicate the DNA deleted by $D f(3 R) W I N 1$ and by $D f(3 R) M A P 2$; stippling indicates uncertainty of the breakpoint positions. $(B)$ A blot of size-fractionated poly $(\mathrm{A})^{+}$early pupal RNA from OreR or from $D f(3 R) W I N 1 / D f(3 R) M A P 2$ animals probed with the proximal $1.0 \mathrm{~kb}$ (EcoRI-PstI) of fragment A (lanes 1 and 2). The blot was reprobed with a $0.9-\mathrm{kb} X h o I-B a m H I$ fragment from the $84 \mathrm{~B} \alpha$-tubulin gene (lanes 3 and 4 ) to determine the relative amounts of RNA from each genotype. (C) A blot of size-fractionated poly $(\mathrm{A}){ }^{+}$RNA $(10 \mu \mathrm{g} /$ lane $)$ from developmentally staged animals probed with fragment E (1.8 kb HindIII-PstI). (D) The same blot shown in $C$ has been reprobed with ribosomal protein 49 (O'Connell and Rosbash 1984) to show the relative quantities of RNA that were loaded in each lane. 
Pultz et al.
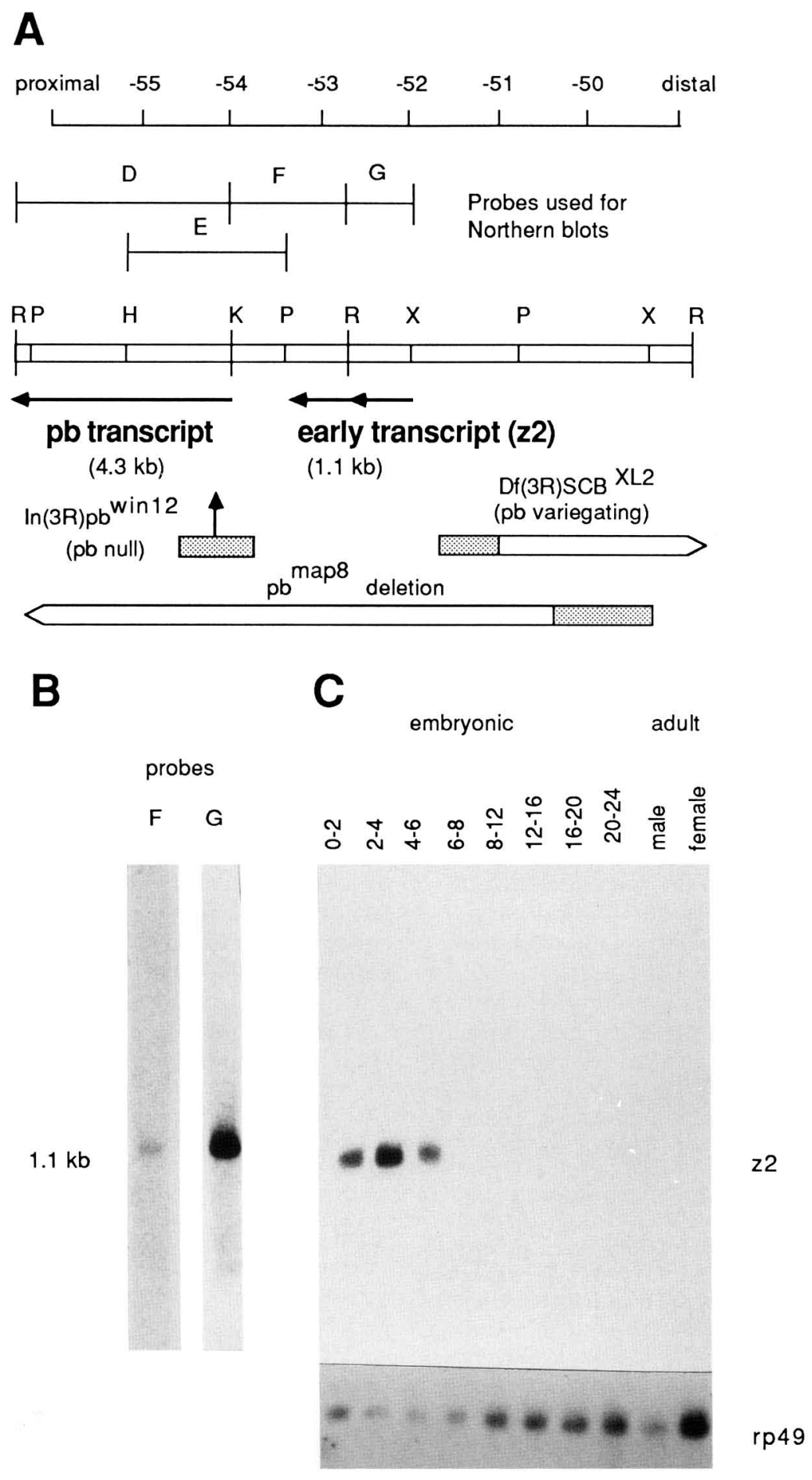

Figure 5. The early embryonic transcription unit $(z 2)$ immediately distal to $p b$. $(A)$ Structure of the -55 to -50 interval. Horizontal arrows indicate restriction fragments that hybridize to the early embryonic transcript or to the $p b$ transcript. Restriction fragments designated D-G refer to probes used for Northern blot experiments; D and E are identical to fragments D and $\mathrm{E}$ in Fig. 4. On the restriction map: $(\mathrm{H})$ HindIII, $(\mathrm{K}) K p n I,(\mathrm{P})$ PstI, $(\mathrm{R})$ EcoRI, and $(\mathrm{X}) \mathrm{XbaI}$. The position of the $\operatorname{In}(3 R) p b^{\text {win12 }}$ breakpoint is indicated by a vertical arrow; open bars indicate the DNA deleted by $D f(3 R) S C B^{X L 2}$ and by the $p b^{\text {maps }}$ deletion. Stippling indicates the extent of the uncertainty of these breakpoints. $(B)$ Poly $(\mathrm{A})+$ RNA $(10 \mu \mathrm{g})$ from 4- to 8-hr embryos was size-fractionated, blotted, and probed with the 1.3-kb KpnI-EcoRI restriction fragment immediately distal to -54 (fragment $\mathrm{F}$ ) and with the adjacent $0.7-\mathrm{kb} E c o R I-X b a I$ fragment (fragment G). More distal genomic sequences did not hybridize detectably to the 1.1-kb RNA. The early embryonic transcript had not been detected with sequences proximal to the PstI site at -53.3 (fragment $\mathrm{E}_{\text {; }}$ see Fig. 4), indicating that all observable homology to the early transcript is between the -53.3 Pst site and the XbaI site. (C) Poly $(\mathrm{A})^{+} \mathrm{RNA}(10 \mu \mathrm{g})$ from staged embryos and adults was size fractionated, blotted, and probed with the $0.7-\mathrm{kb} E c o R I-X b a I$ restriction fragment (fragment G), then reprobed for rp49 as indicated in the legend to Figure 4. 

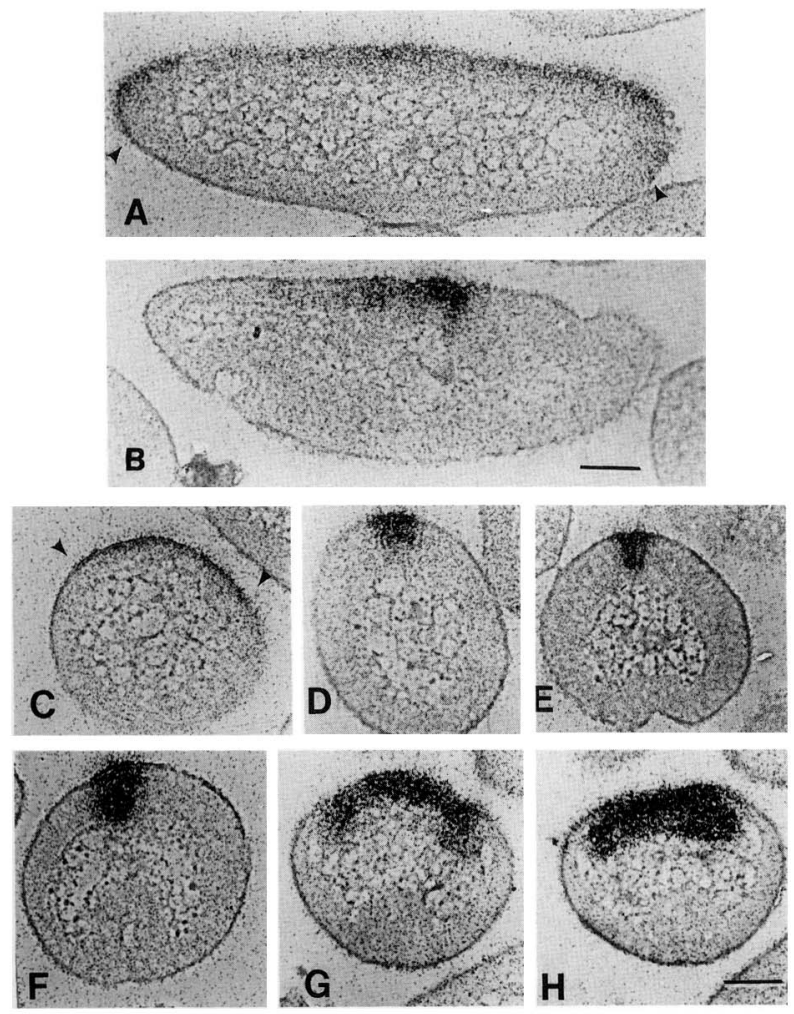

Figure 6. Localization of transcripts of the early embryonic transcription unit $(z 2)$ immediately distal to $p b$. $(A)$ Sagittal section of a cycle-13-14 embryo, at $\sim 2 \mathrm{hr}$. Arrowheads mark the limits of grain localization. $(B)$ Sagittal section of a gastrulating embryo. $(C)$ Cross section of a cycle 11-12 embryo. Arrowheads mark the limits of grain localization. $(D)$ Cross section of an embryo during cellularization. $(E, F)$ Cross sections showing localization of $z 2$ transcripts as gastrulation proceeds. $(G, H)$ Serial cross sections through region of the dorsal folds, at about $3.5 \mathrm{hr}$.

described here are estimated from the description of embryogenesis by Hartenstein and Campos-Ortega (1985). No evidence of $p b$ protein accumulation is observed during the blastoderm stage of embryogenesis or during gastrulation and germ-band elongation. However, just as the gnathal buds are beginning to form, between $\sim 5.5$ and $6 \mathrm{hr}$, detectable $p b$ protein first appears quite abruptly in a group of nuclei in the region of the presumptive mesoderm directly behind the stomodeum (Fig. 7A,B). This relatively abrupt appearance of $p b$ protein in cells of the mesodermal region contrasts with the gradual accumulation observed for subsequent $p b$ protein expression in the ectoderm and in the central nervous system. The early $p b$ staining pattern in the mesodermal region is dynamic: Cells expressing the $p b$ protein appear to migrate away from the ventral midline as the maxillary and labial buds take shape, separating bilaterally into two groups (Fig. 7C,D). This staining pattern dissipates toward the beginning of germ-band retraction, after $7 \mathrm{hr}$ (Fig. 7E,F), leaving about six to eight cells with large and strongly staining nuclei internal to each mandibular lobe. Mesodermal staining can be followed subsequently in a group of cells with very small nuclei that migrate dorsally and posteriorly, taking their places along the walls of the foregut (see below). Figure $7, \mathrm{C}-\mathrm{F}$ also shows the appearance of weak $p b$ staining in the labial and maxillary lobes. Figure $7, G$ and $H$, shows that as the germ band retracts, $p b$ protein becomes more concentrated in the ectodermal nuclei of the labial and maxillary lobes. In addition, $p b$ staining is observed in a group of cells in a ventral, or sternal, location, which originate between the posterior mandibular and anterior maxillary lobes. The accumulation of $p b$ protein in the labial and maxillary lobes progresses in an uneven fashion.

At the end of germ-band retraction, at $\sim 9.5 \mathrm{hr}$, staining in the labial lobes and the sternal region has become quite intense (Fig. 8A). Staining in the maxillary lobes has also become intense; in addition, the nuclei internal to the mandibular lobes still stain very strongly (Fig. 8B). As the labial lobes fuse at the ventral midline and involute into the stomodeum, between $\sim 10$ and 12 $\mathrm{hr}, p b$ protein in the nuclei of these cells approaches its maximal accumulation; thus, the peak of $p b$ protein accumulation occurs several hours after the embryonic peak of $p b$ message accumulation (see Fig. 4C). By about $10 \mathrm{hr}, p b$ protein expression appears to be excluded from a small region of each labial lobe (Fig. $8 \mathrm{C}$ ), probably cor- 

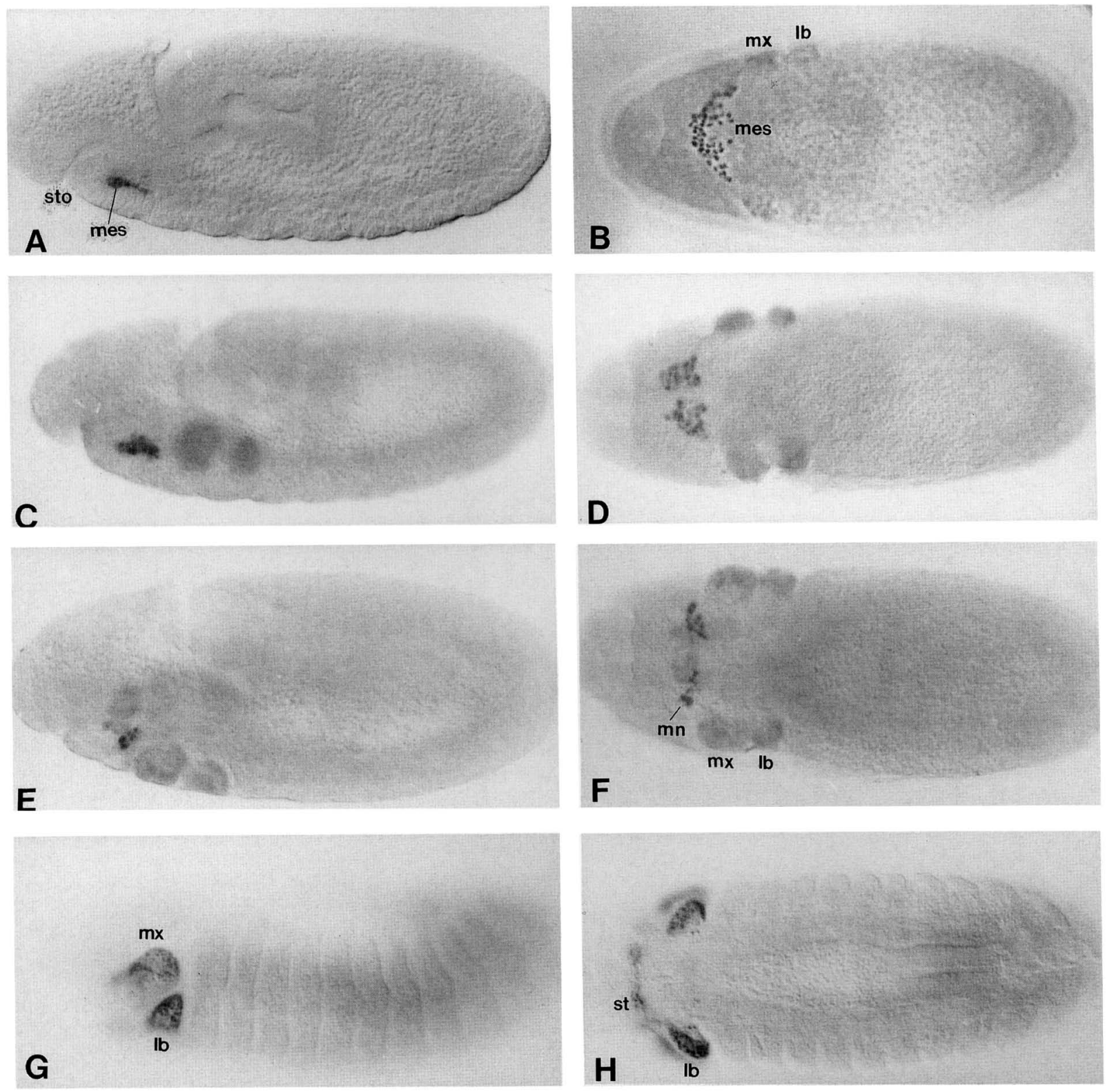

Figure 7. Early expression patterns of $p b$ protein during embryogenesis. $(A)$ The onset of $p b$ protein expression is observed in the mesodermal layer (mes) directly behind the stomodeum (sto), seen in a sagittal view. $(B)$ Horizontal view of the earliest detectable $p b$ protein expression, between 5.5 and $6 \mathrm{hr}$. The $p b^{+}$nuclei correspond to the mesodermal cells seen in $A$. Maxillary (mx) and labial (lb) buds are just beginning to form. $\left\{C, D \mid\right.$ Sagittal and horizontal views of an embryo at $\sim 6.5 \mathrm{hr}$. The $p b^{+}$cells of the mesodermal region no longer span the midline and now appear in two clusters. A gradual onset of $p b$ protein accumulation is seen in the labial and maxillary buds, which are becoming morphologically distinct. $(E, F)$ Sagittal and horizontal views of an embryo between 7 and $7.5 \mathrm{hr}$. The morphogenetic rearrangements of the maxillary and labial lobes are beginning. The mesodermal staining pattern is dissipating, and the strongest staining is becoming restricted at this point to two small clusters of cells internal to the mandibular lobes (mn). $(G, H)$ Lateral and ventral horizontal views of an embryo, nearing the end of germ-band retraction, at $\sim 9 \mathrm{hr}$. The maxillary lobes are now situated dorsal to the labial lobes. The accumulation of $p b$ protein in the maxillary and labial lobes is becoming prominent by this stage.

responding to the labial sensory anlagen described by Turner and Mahowald (1979). The original $p b^{+}$cells internal to the mandibular lobes are still staining strongly; in addition, a cluster of $p b^{+}$cells is detected internal to the maxillary lobes (Fig. 8D). The maxillary lobes have undergone considerable dorsal displacement; these cells are expressing $p b$ protein at high levels (Fig. 8E). At this point, $p b$ protein is also observed in a group of cells with very small nuclei, which have migrated to the vicinity of the posterior foregut (Fig. 8F). These cells will later be 

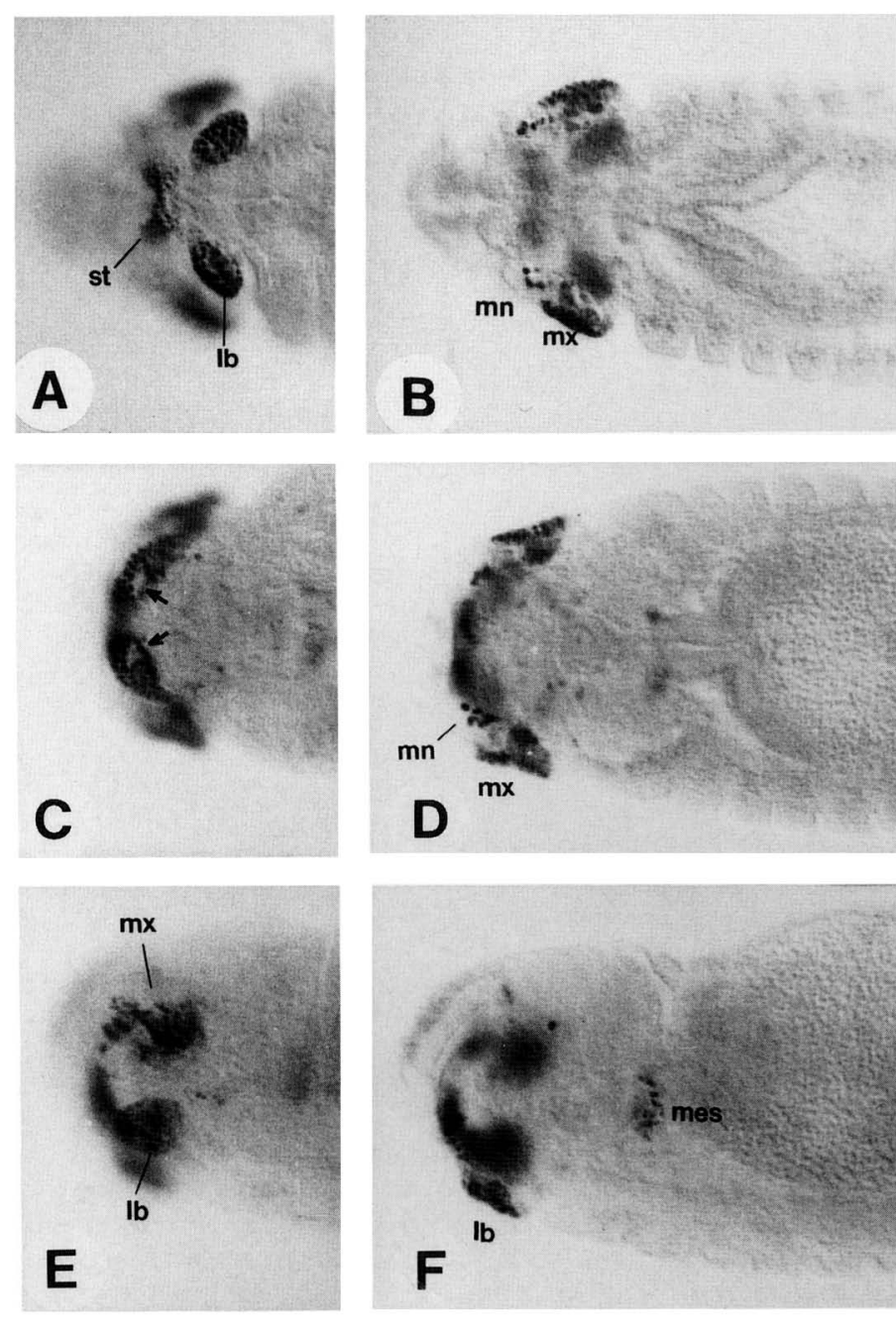

B
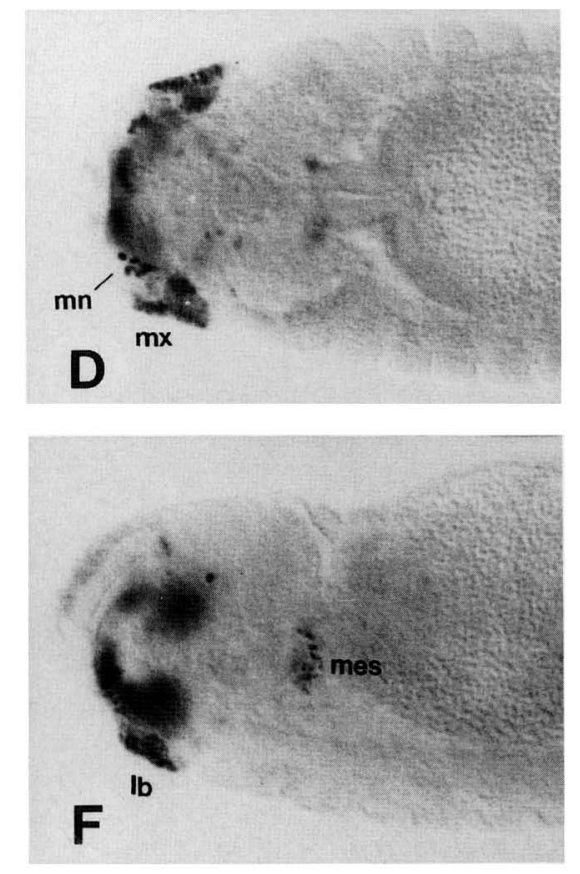

Figure 8. Expression of $p b$ protein at mid-embryogenesis. ( $A$ and $B$ ) Two different views of the same embryo, which is $\sim 9.5 \mathrm{hr}$ in age. $(A)$ Horizontal view, ventral aspect. Localization of $p b$ protein is seen in the labial lobes (lb) and in the sternal region $(\mathrm{st}) .(B)$ Horizontal view, dorsal to $A$. Localization of $p b$ protein is seen in the maxillary lobes $(\mathrm{mx})$; in addition, a cluster of $p b^{+}$cells with relatively large nuclei are located internal to each mandibular lobe $(\mathrm{mn}) .(C-F)$ Four different views of the same embryo, which is -10-10.5 hr. in age. (C) Horizontal view, ventral aspect, showing the labial lobes. As the labial lobes move toward the ventral midline, a small region appears on each labial lobe, which is free of detectable $p b$ protein expression. These appear to correspond to the labial lobe indentations observed in scanning electron micrographics, which represent anlagen of the labial sense organs (Turner and Mahowald 1979). (D) Horizontal view, dorsal to the view shown in $C$. Staining is visible in the ectoderm of the maxillary lobes and in clusters of cells internal to the mandibular and maxillary lobes. $(E)$ Lateral view, showing $p b^{+}$nuclei in the labial (lb) and maxillary ( $\mathrm{mx}$ ) lobes. The internal mandibular cells $(\mathrm{mn})$ and the sternal region (st) are out of the plane of focus. $(F)$ Medial view, showing one labial lobe and the sternal region in focus. In addition, a cluster of $p b^{+}$mesodermal cells with very small nuclei are seen in the posterior region of the foregut. found around the esophagus and proventriculus (not shown).

During head involution, staining in the gnathal segments remains strong, and expression of $p b$ protein in the central nervous system is also detected, in a pattern that becomes increasingly complex (Fig. 9). At first, evidence of $p b$ protein expression in the nervous system is limited to a very small subset of cells in the supraesophageal ganglion (Fig. 9B), in the subesophageal ganglion (Fig. 9A,C), and in the region of the ventral nerve cord derived from the first three thoracic segments (Fig. $9 A, D)$. Subsequently, $p b$ protein also appears in a subset of cells in the abdominal region of the ventral nerve cord (Fig. 9E). The first six abdominal segments show an expression pattern distinct from that observed in the thoracic segments, whereas the more posterior abdominal segments appear to express only the peripheral components of the anterior abdominal pattern. Expression of $p b$ protein in the central nervous system becomes more prominent as the nerve cord shortens, after $\sim 16 \mathrm{hr}$ (Fig. $9 F, G)$. However, the set of cells expressing $p b$ protein never constitutes more than a very small proportion of central nervous system cells in any given segment.
In contrast to the gnathal ectoderm and the central nervous system, note that there is no evidence of $p b$ expression in the region of the dorsal fold (Fig. 9A). Precursors of the eye-antennal discs are invaginating into the frontal sac in this region. These cells ultimately will give rise to much of the head, including the maxillary palps (Haynie and Bryant 1986).

\section{Discussion}

We have identified the $p b$ locus in the proximal ANT-C through the analysis of $p b$ null chromosomal rearrangements. Transcriptional analysis reveals that a $4.3-\mathrm{kb}$ RNA size class is detected with genomic restriction fragments from both ends of a $34-\mathrm{kb}$ interval, which closely corresponds to the interval defined genetically as essential for $p b$ function. On this basis, we have designated the 4.3-kb RNA as the $p b$ RNA. Immediately distal and $5^{\prime}$ to the $p b$ transcription unit, there is an additional transcription unit, $z 2$, which is expressed dorsally during embryogenesis in a pattern resembling that of the zen locus.

We have also analyzed two chromosomal rearrange- 

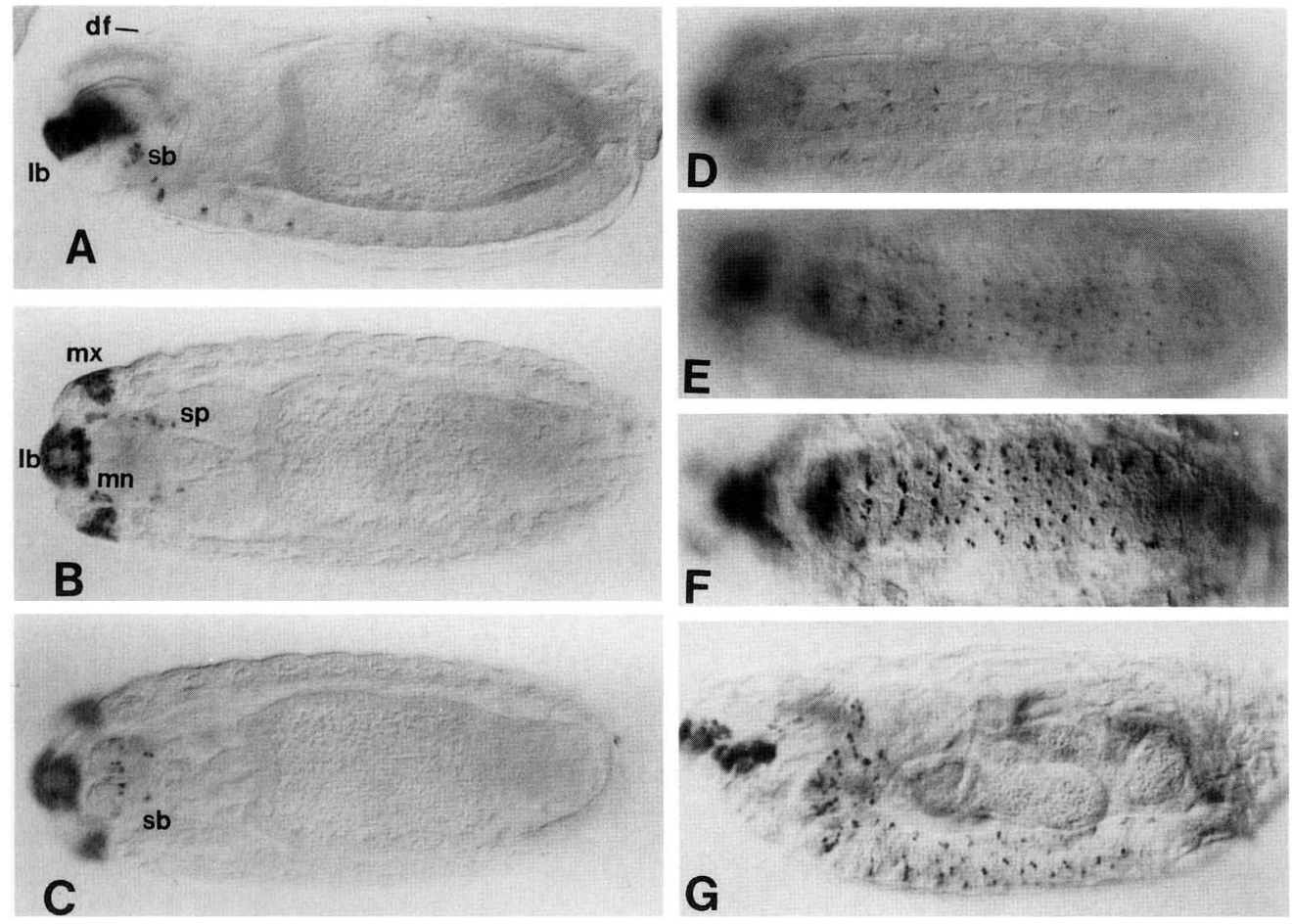

Figure 9. Localization of $p b$ protein in the embryonic central nervous system. Optical sections of embryos stained with anti-pb antibodies. $(A-D)$ Sagittal view and three horizontal optical sections of an embryo undergoing head involution. $(A)$ Sagittal view, showing $p b$ protein localization in the involuting labial lobes and in a few cells in the anterior portion of the ventral nerve cord, including the subesophageal ganglion (sb). No $p b$ staining is apparent in the dorsal fold (df). (Note that the 'dorsal fold', derived from the dorsal ridge, is distinct from the dorsal folds in which $z 2$ expression was observed earlier in embryogenesis.) $(B)$ Horizontal view, showing $p b$ protein localization in cells derived from the labial lobes (now mostly internal) and maxillary lobes (still external); in addition, $p b$ protein is localized in a few nuclei in the supraesophageal ganglion $(\mathrm{sp})$. (C) Horizontal view ventral to the view shown in $B . p b$ protein is seen in a few nuclei in the subesophageal ganglion (sb). (D) Ventral horizontal view, showing $p b$ protein localization in a few cells in the anterior portion of the ventral nerve cord. $(E, F)$ Ventral horizontal views of sequentially older embryos. After initial expression is detected in the anterior portion of the nerve cord, as in $D$ above, $p b$ protein expression is subsequently detected in a small subset of cells extending throughout most of the length of the ventral nerve cord. Note that the expression pattern of $p b$ protein in the posterior central nervous system differs both temporally and spatially from the expression observed more anteriorly. (G) Sagittal view of an embryo that is approximately the same age as the embryo shown in $F$.

ments that partially complement $p b$ in a variegating fashion. These two chromosomes have breakpoints distal and $5^{\prime}$ to both the $p b$ and $z 2$ transcription units. One chromosome, $\operatorname{In}(3 R) M A P 17$, is an inversion of ANT-C sequences into heterochromatin; the other, $D f(3 R) S C B^{X L 2}$, appears to be an entirely euchromatic deficiency. The effects of these breakpoints on $p b$ function may be due entirely to heterochromatic and euchromatic position effects, respectively (Spofford 1976; Levis et al. 1985). Alternatively, some of the regulatory sequences necessary for wild-type $p b$ function may be removed in one or both of these chromosomal rearrangements, which have breakpoints mapping between 2 and $7 \mathrm{~kb}$ upstream of the $p b$ transcription unit. Whatever the mechanism(s) responsible for the $p b$ variegating phenotypes, it is notable that the labial palp transformations of $p b$ variegating $/ p b^{-}$individuals always consist of leg-like structures. Thus, the affected cells follow a developmental pathway indicative of a complete loss of $p b$ function; this pathway is distinct from the labial-to-ar- istal transformations observed in previously described hypomorphic $p b$ alleles (Kaufman 1978).

\section{Expression of pb-gene products during embryogenesis}

The function of $p b$ is similar to the functions of other ANT-C homeotic genes, such as $S c r, D f d$, and $l a b$ in that $p b$ plays an essential determinative role in adult head development. However, $p b$ is unique among ANT-C homeotic genes in that it lacks an obvious role in embryonic development. We examined the temporal expression profile of $p b$ transcripts with the expectation that the adult-specific nature of $p b$ developmental effects might well be reflected in a preponderance of $p b$ expression at the pupal stage of the life cycle. However, $p b$ transcripts are expressed as prominently during embryogenesis as during the pupal period. In addition, these transcripts direct the synthesis of embryonic $p b$ protein, as determined by raising antibodies against a $\beta$-galactosidase fusion protein containing $p b$ protein-coding sequences. 
Embryonic $p b$ protein is observed in most ectodermal cells of the labial and maxillary lobes, as well as in more anterior ventral ectoderm. In addition, $p b$ protein is observed in cells of the mesoderm and central nervous system. The $p b$ protein is localized to nuclei, like the protein products of other homeotic genes of the BX-C and ANT-C (Beachy et al. 1985; White and Wilcox 1985; Carroll et al. 1986; Wirz et al. 1986; Mahaffey and Kaufman 1987; Riley et al. 1987; R. Diederich, unpubl.). No evidence of $p b$ protein expression has been observed in late third instar imaginal discs using this anti-pb antibody; however, the major peaks of $p b$ transcript accumulation occur during the second day of larval life and during the second day of pupation.

The pattern of $p b$ protein expression during embryogenesis shares many general features with the expression of other ANT-C genes such as Antp, Scr, and Dfd: A segmentally restricted pattern is observed in the ectoderm, and expression extends to a discrete subset of cells in the mesoderm and central nervous system. However, the pattern of $p b$ protein expression in the central nervous system differs strikingly from the patterns of transcript and/or protein expression in the central nervous system observed for the other ANT-C homeotic genes (Carroll et al. 1986; Wirz et al. 1986; Mahaffey and Kaufman 1987; Riley et al 1987; Chadwick and McGinnis 1987; Martinez-Arias et al. 1987; R. Diederich, unpubl.). Each of the other ANT-C genes shows extensive expression in at least one segmental division of the central nervous system. In contrast, $p b$ protein is expressed in only a small subset of central nervous system cells in any given segment. In addition, the terminal pattern of $p b$ protein expression is unusual in that it extends throughout the length of the central nervous system.

Many homeotic genes are required and expressed in parasegmental rather than segmental domains, such that the boundaries of a gene's function and expression lie within segments rather than between segments (Martinez-Arias and Lawrence 1985; for review, see Akam 1987). The expression of $p b$ protein in the ectoderm does not conform to this generalization. The posterior limit of $p b$ expression lies at the posterior edge of the labial lobe, which appears to be a segmental structure, as judged by the position of cells expressing the engrailed protein (DiNardo et al. 1985). In this regard, $p b$ expression parallels the expression of $D f d$, which extends from the mandibular segment to the posterior margin of the segmental maxillary lobe (Chadwick and McGinnis 1987; Martinez-Arias et al. 1987).

The spatial expression of embryonic $p b$ protein overlaps the expression of $S c r$ and $D f d$ transcripts and protein products. $S c r$ transcripts and protein products are expressed primarily in the labial and first thoracic segments (Kuroiwa et al. 1985; Levine et al. 1985; Mahaffey and Kaufman 1987; Martinez-Arias et al. 1987; Riley et al. 1987), thereby overlapping $p b$ expression in the labial lobe. $D f d$ transcripts and protein products are expressed in the maxillary and mandibular segments (Chadwick and McGinnis 1987; Martinez-Arias et al.
1987; R. Diederich, unpubl.), overlapping $p b$ expression in the maxillary lobe and in the sternal region. The expression of $S c r$ in the labial lobe correlates with phenotypic defects in labially derived larval cuticular structures of $\mathrm{Scr}^{-}$embryos. These embryos lack the hypostomal sclerite and the H-piece bridge (V. Merrill, unpubl.), which are derived from the labial portion of the blastoderm according to fate-mapping studies (Jürgens et al. 1986). In addition, $\mathrm{SCr}^{-}$embryos show a duplication of the maxillary sense organ (Struhl 1983; Sato et al. 1985), which may represent a labial-to-maxillary transformation. Similarly, expression of $D f d$ transcripts in the maxillary and mandibular segments correlates with defects in cuticular structures of maxillary and mandibular origin in $D f d^{-}$embryos. In these embryos, the maxillary cirri, maxillary sense organs, mouth hooks, and $\mathrm{H}$ piece lateral bars are defective (Merrill et al. 1987; Regulski et al. 1987). In contrast, genetically marked $\mathrm{pb}^{-}$ larvae show no obvious cuticular defects corresponding to the labial, maxillary, and mandibular domains of $p b$ expression in embryos.

There are several possible explanations for the discrepancy between the embryonic $p b$ expression pattern and the apparently adult-specific nature of the $p b$ phenotype. One possibility is that the embryonic $p b$ expression pattern may be without function, e.g., such expression might be an evolutionary vestige. Interestingly, there is evidence that a potential $p b$ homolog in a more primitive insect plays an essential role in larval as well as adult development: A loss-of-function mutation at the maxillopedia locus in Tribolium results in labial-to-leg transformations both in the larva and in the adult (Beeman 1987).

Alternatively, the embryonic pattern of ectodermal $p b$ expression might be an inelegant mechanism to ensure the segmental identities of those few cells that will ultimately give rise to adult cuticular structures. The temperature-shift experiments of Villee (1944) demonstrate that $p b$ function is required during larval and early pupal development. However, these experiments were not designed to assess the role of $p b$ during embryogenesis and do not exclude the possibility that $p b$ function might play an additional determinative role during embryogenesis.

Though embryonic $p b$ expression in the labial lobe might influence subsequent development of the labial palps, there is no reason to believe that $p b$ expression in the embryonic maxillary lobe influences maxillary palp development. Due to the complex rearrangements that take place during head development in Drosophila, the maxillary palps do not develop from separate maxillary imaginal anlagen as in more primitive dipterans; instead, they develop from the eye-antennal discs (Haynie and Bryant 1986; Jürgens et al. 1986). We have detected no evidence of embryonic $p b$ protein expression in cells of the dorsal ridge or frontal sac, which give rise to the eye-antennal disc [in contrast, products of the $D f d$ and $l a b$ loci are clearly expressed in the dorsal ridge (Chadwick and McGinnis 1987; R. Diederich, unpubl.)]. In addition, observations of sequentially older embryos reveal 
no evidence that there is any migration of $p b^{+}$cells from the maxillary lobes to the region of frontal sac formation. Thus, there appears to be no direct connection between the observed embryonic pattern of $p b$ protein expression and determination of the adult maxillary palps.

It is also possible that $p b$ may have very subtle functions in Drosophila embryogenesis, in addition to its functions in adult development. For example, $p b$ may influence aspects of cellular identities that are not discernible through analysis of larval cuticular structures. Alternatively, embryonic $p b$ gene products may have stabilizing or 'buffering' effects on the expression of other homeotic genes, rather than carrying out directly determinative functions. Another possibility is that the functions of $p b$ gene products might not be revealed in $p b^{-}$individuals because they can be supplied redundantly by other genes, e.g., the $D f d$ and/or $S c r$ loci discussed above.

Whether $p b$-gene products have developmental functions in the embryonic mesoderm or central nervous system is an open question, though such possible functions are clearly not critical for larval survival. However, it is known that $p b$ plays a role in the development of the adult peripheral nervous system: Stocker (1982) showed that the loss of $p b$ function affects the pathways chosen by the axons of sensory neurons in the ectopic antenna-like or leg-like appendages.

\section{The $\mathrm{z} 2$ locus}

The $z 2$ locus is located between the $p b$ transcription unit and the $p b$ variegating breakpoints; yet the spatial pattern of $z 2$ transcript expression appears totally unrelated to that of $p b$. Instead, $z 2$ is expressed in a pattern very similar to that of its distal neighbor, the zen locus. For a detailed comparison of $z 2$ and zen expression and structure, see Rushlow et al. (1987); these investigators report that the $z 2$ transcription unit contains a homeo box very similar in structure to that of the zen homeo box but that DNA sequence similarity between the two genes does not extend outside of their homeo box sequences.

We report that the $z 2$ transcription unit can be deleted without conferring embryonic lethality or larval pattern defects. In contrast, homozygous zen- individuals die as embryos with a variety of cuticular defects, including a characteristic failure to undergo proper head involution (Wakimoto and Kaufman 1981). It is clear from our breakpoint analysis that the zen locus is distal to $z 2$, as zen point mutants complement the $p b^{\text {map } 8}$ deletion. Moreover, Rushlow et al. (1987) have demonstrated by germ-line transformation experiments that the more distal zen transcription unit rescues the embryonic lethality of the $z e n^{w 36}$ null allele.

There are several possible explanations for the lack of an apparent phenotype in individuals deleted for the $z 2$ homeo box gene. First, there may be a subtle phenotype that has escaped our detection. We have examined the cuticular pattern of genetically marked first instar larvae and of pharate adults; however, embryonic phenotypes have been difficult to evaluate due to an inseparable $2 ; 3$ translocation associated with the $p b^{\text {map8 }}$ chromosome. It is unlikely that our inability to detect a phenotype in $z 2^{-}$animals is due to a significant maternal contribution of $z 2$ gene products, as the peak of localized $z 2 \mathrm{ex}-$ pression in embryos is clearly of zygotic origin and no $z 2$ transcripts are detected in adult females. Second, $z 2$ may have no function in Drosophila melanogaster. A third possibility is that $z 2$ may have a developmental function similar or identical to that of some other gene(s) such that compensating function is supplied in $z 2^{-}$embryos by other gene(s). If such functional equivalents exist, they must be sufficiently divergent structurally as to go undetected on whole genome Southern blot experiments: $z 2$ protein-coding sequences (excluding the $z 2$ homeo box) do not detect additional related sequences at low stringencies (D. Cribbs, unpubl.). Conceivably, such a function could be supplied by the zen locus.

An example of probable functional redundancy involving homeo box genes has been reported in the gooseberry region. There, two adjacent transcription units show a related spatial expression pattern suggestive of gooseberry function, yet the embryonic lethal gooseberry phenotype is obtained only if both transcription units are removed (or significantly reduced in expression) (Bopp et al. 1986; Côté et al. 1987). Another example of adjacent homeo box genes that are very similar to one another in their expression patterns is found in the engrailed region (Coleman et al. 1987). In this case, the genetically essential engrailed transcription unit is closely linked to the related invected transcription unit, for which no detectable genetic function has been reported.

\section{Conclusions}

We have identified the homeotic $p b$ locus in the proximal ANT-C and report that the $p b$ transcription unit corresponds closely to the interval defined by a series of $p b$ null rearrangement breakpoints. The $z 2$ homeo box gene (Rushlow et al. 1987) lies immediately distal to the $p b$ transcription unit. Distal and $5^{\prime}$ to both transcription units, we have mapped two chromosomal breakpoints that affect $p b$ function in a variegating fashion. When both the $p b$ and $z 2$ transcription units are deleted, no effects on the development of larval cuticular structures are detected, yet both $p b$ and $z 2$ are expressed in spatially localized patterns during embryogenesis. The expression of $p b$ protein throughout the ectoderm of the labial and maxillary lobes parallels the segmentally restricted expression of the embryonically essential ANT-C homeotic loci. Like other homeotic genes, $p b$ is also expressed in the mesoderm and in the central nervous system, though the pattern of $p b$ expression in the nervous system is atypical. On the other hand, the $z 2$ locus is expressed in a pattern that resembles the expression of the neighboring zen locus. Thus, the molecular expression patterns of $p b$ and $z 2$ during embryogenesis reveal similarities to other ANT-C genes, although these similarities are not reflected in comparable phenotypic consequences. 


\section{Materials and methods}

\section{Isolation of mutant chromosomes}

All of the $p b$ null chromosomes isolated by M.A.P. and T.C.K. were obtained in a standard $F_{1}$ screen for loss of $p b$ function. Males (see Table 1 for parent stocks) were irradiated with $\mathrm{X}$ rays at $3500-4000$ rads and mated to homozygous $p b^{f 4}(\mathrm{P}$. Fornili and T. Kaufman, unpubl.) or $p b^{f 4} / p b^{4}$ (Kaufman 1978) females. $F_{1}$ progeny, which had antennal structures emerging from the labial palps, were selected and used to establish balanced stocks, which were then tested for their ability to complement ANT-C loci. The In(3R)MAP17 chromosome was isolated in a standard $F_{2}$ screen for lethal and visible mutations, as described by V. Merrill et al. (in prep.).

\section{Breakpoint mapping}

Table 1 notes which of the following procedures were used for breakpoint mapping and confirmation for each of the mutant chromosomes.

A Genomic DNA was prepared from balanced stocks of the mutant chromosomes, from stocks of the parent chromosomes, and from balanced stocks of deficiency chromosomes, which served as controls for balancer chromsome sequences. Each genotype was restricted with four restriction enzymes and probed with radiolabeled $\lambda$ phage DNA containing genomic inserts from the $p b$ region.

B Same as A, except that purified restriction fragments or plasmid subclones were used as probes to refine the location of the breakpoints.

C To confirm deleted sequences, DNA was prepared from individuals bearing overlapping deficiency chromosomes and therefore completely deleted for a given interval, and either (Cl) this genomic DNA was used on genomic Southern blots, with appropriate controls, as in A or B above; or $(\mathrm{C} 2)$ the genomic DNA was labeled by nick translation or oligo priming (Feinberg and Vogelstein 1983) and used to probe blots of cloned sequences from the $p b$ region to determine which sequences were deleted.

D For $D f(3 R) S c x^{W+R x 2}$, a $\lambda$ phage library was constructed from $D f(3 R) S C X{ }^{W+R X 2} / T M 3$ individuals, and a clone was isolated that contained the deficiency junction.

E For $\operatorname{In}(3 R) M A P 17$, the lesion at -48 was implicated as the inversion breakpoint by recovering an X-ray-induced distal deficiency derivative of this chromosome and comparing DNA from the two lines on genomic Southern blots.

\section{Examination of $\mathrm{pb}^{-}$larvae for cuticular defects}

To examine $p b^{-}$larvae for possible cuticular defects, the TM3 $\mathrm{y}^{+}$chromosome (Lindsley and Grell 1968) was used to allow unambiguous identification of individuals deleted for the $p b$ locus. $y^{1} w ; D f(3 R) M A P 2 / T M 3 y^{+}$virgins were crossed to $y^{1} w$; $p b^{\text {map } 8} / T M 3 y^{+}$males or to $y^{1} w ; D f(3 R) W I N 3 / T M 3 y^{+}$males, and $12 \mathrm{hr}$ collections of embryos were obtained in egg-laying containers. First instar larvae with yellow mouthparts were removed from the plates, mounted in polyvinyl lactophenol (PVL) (Garr), and left to clear for $24 \mathrm{hr}$ at $56^{\circ} \mathrm{C}$. Larvae were examined with phase optics at $40 \times$ for the presence of labial sense organs, labial black dots, ventral organs, maxillary sense organs, and hypopharyngeal organs (Jürgens et al. 1986). Each of these sense organs was present and appeared normal in these animals; in addition, no duplications of sense organs were detected. Components of the cephalopharyngeal skeleton and maxillary cirri also appeared normal.

\section{Examination of $\mathrm{pb}^{-} \mathrm{z}^{-}$- larvae}

To determine whether any larval defects resulted from deletion of the $z 2$ transcription unit in addition to the $p b$ transcription unit, $y^{1} w D f(3 R) M A P 11 / p b^{\text {map8 }}$ embryos were collected and examined as described for $\mathrm{pb}^{-}$embryos in the previous section ( $D f(3 R) M A P 11$ is a deficiency that fails to complement all loci from lab through $D f d$ in the ANT-C). In addition to examining the structures described above, larvae were examined for defects in the setal belts and in posterior structures, but no such defects were detected.

\section{Northern blot analysis and in situ hybridization}

Total RNA was isolated from staged Oregon R (OreR) P2 embryos, larvae, and pupae (raised at $25^{\circ} \mathrm{C}$ ) by the guanidine isothiocyanate/cesium chloride method (Chirgwin et al. 1979). RNA from adult OreR P2 flies was extracted by the phenol/SDS method (Spradling and Mahowald 1979). Poly|A ${ }^{+}$RNA was prepared by passage of total RNA through an oligo(dT) (Collaborative Research) column (Aviv and Leder 1972). Poly(A) ${ }^{+}$RNA was eluted in water and selected a second time. Poly $(\mathrm{A}))^{+}$RNA $(10 \mu \mathrm{g} /$ lane) was size-fractionated on a $1 \%$ agarose/formaldehyde gel. The gel was stained with ethidium bromide; visual examination confirmed that each lane contained approximately an equal amount of RNA. The fractionated RNA was electroblotted onto Nytran (Schleicher and Schuell) and UV-irradiated according to Khandiian (1987). Hybridization was carried out at $42^{\circ} \mathrm{C}$ for $18 \mathrm{hr}$ at a stringency of $50 \%$ formamide, $5 \times$ SSC. The final wash was for $1 \mathrm{hr}$ at $65^{\circ} \mathrm{C}$ in $0.5 \times$ SSC, $0.5 \%$ SDS. The DNA probe was labeled with $[\alpha-32 \mathrm{P}] \mathrm{dATP}$ using Klenow fragment of Escherichia coli DNA polymerase I (Boehringer Mannheim) and random oligonucleotides (Molecular Biology Institute, Indiana University) as primer (Feinberg and Vogelstein 1983). Approximately $6 \times 10^{7} \mathrm{cpm}$ of the ${ }^{32}$-labeled DNA probes (sp. act. $=6 \times 10^{8} \mathrm{cpm} / \mu \mathrm{g}$ ) were used for each experiment. Hybridization of Northern blots under these conditions often results in the presence of a band at $1.9 \mathrm{~kb}$, regardless of the sequences used in the probe. We have seen this band using almost all probes from the $p b$ and $l a b$ regions of the ANT-C; in addition, the intensity of this band diminishes relative to $p b$ or $l a b$ transcripts when extremely high stringencies are used. Thus, we do not believe that the 1.9 -kb band represents specific hybridization.

The direction of transcription for the $p b$ transcription unit was determined by hybridizing strand-specific RNA probes to Northern blots. Three EcoRI restriction fragments (fragments A, B, and D, Fig. 4) were subcloned into pGEM2 (Promega Biotec). RNA transcripts were synthesized in vitro using either SP6 or T7 polymerase (Promega Biotec) and $\left[\alpha^{-32}\right.$ P UTP. Hybridization was carried out at $65^{\circ} \mathrm{C}$ in $65 \%$ formamide and $2 \times$ SSC. A final wash of $5 \mathrm{~mm}$ Tris (pH 8), $0.2 \mathrm{mM}$ EDTA, $0.05 \%$ sodium pyrophosphate, and $0.1 \times$ Denhardt's solution at $70^{\circ} \mathrm{C}$ was necessary to eliminate nonspecific hybridization of the RNA probes. The direction of transcription of $z 2$ was determined by the same method, using the 700-bp EcoRI-XbaI restriction fragment (fragment G, Fig. 5) as the probe.

In situ hybridizations were performed using $\left[{ }^{35}\right.$ S $]$ UTP-labeled single-stranded RNA probes, by the method of Ingham et al. (1985).

\section{Expression of the $\beta$-galactosidase-pb fusion protein}

DNA sequence analysis revealed putative $p b$ protein-coding sequences in the 1.7-kb genomic EcoRI fragment (fragment B, Fig. 4); a restriction map of this EcoRI fragment is shown in Figure 


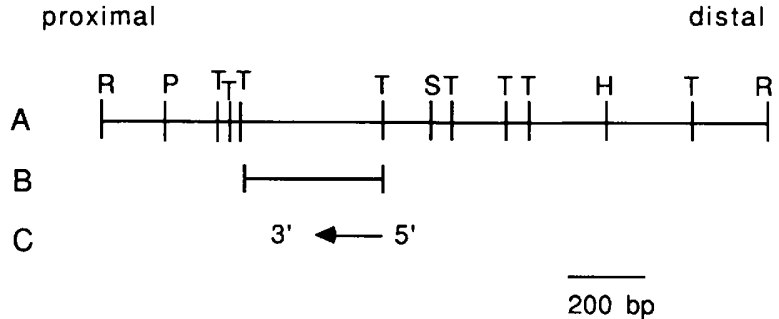

Figure 10. Restriction map showing genomic $p b$ proteincoding sequences used to construct the $\beta$-galactosidase- $p b$ fusion protein. (A) Restriction map of a 1.7-kb genomic EcoRI fragment (fragment $B$, Fig. 4) from the protein-coding portion of the $p b$ transcription unit (D. Cribbs et al., in prep). $(B)$ Position of the 0.4-kb genomic TaqI fragment that was used to generate the $\beta$-galactosidase $-p b$ fusion protein. $(C)$ Orientation and approximate extent of the protein-coding sequences. The fusion protein contained a sequence of 59 amino acids derived from the $p b$ genomic restriction fragment, extending through exonic protein-coding sequences to an intronic stop codon. All but the last 13 of these 59 amino acids are coextensive with the predicted amino acid sequence of a $p b$ cDNA clone (D. Cribbs et al., in prep).

10. The 0.4-kb TaqI fragment shown in Figure 10 was cloned into the AccI site of pWR 590 (Guo et al. 1984). The fusion protein was expressed in JM83 cells grown in LB, $50 \mu \mathrm{g} / \mathrm{ml} \mathrm{am-}$ picillin; these cells have a defective lac repressor. Preparation of protein from these cells was as described in Leaf et al. (1987).

\section{Production and purification of antibodies}

The $\beta$-galactosidase $-p b$ fusion protein was prepared for injection by excising the appropriate band from a $6.5 \%$ SDS-polyacrylamide gel, grinding the gel slice to a powder in liquid nitrogen, and mixing the powder $1: 3$ in Freund's adjuvant. Complete adjuvant was used for the first boosts, and incomplete adjuvant was used thereafter. Dutch belted rabbits were injected biweekly for the first four boost and monthly thereafter, with about $300 \mu \mathrm{g}$ of protein per injection. Serum collected after the third boost contained no detectable anti- $p b$ antibodies. The serum used to stain embryos in Figures 7 and 8 was collected after the sixth boost. Serum from two different rabbits gave identical results.

Antibodies were affinity-purified by passing the serum repeatedly through a $\beta$-galactosidase affinity column to deplete the serum of antibodies raised against the $\beta$-galactosidase portion of the fusion protein. The flowthrough material from this column was then passed repeatedly through a $p b-\beta$-galactosidase fusion protein affinity column, made by coupling the fusion protein to Affigel 10 matrix (Bio-Rad). Antibodies were eluted from this column with $0.1 \mathrm{M}$ glycine $(\mathrm{pH} 2.5)$, then neutralized with one-tenth volume of $2.0 \mathrm{M}$ Tris $(\mathrm{pH} 7.6)$. Sodium azide was added to $0.025 \%$, and the antibodies were stored at $4^{\circ} \mathrm{C}$.

\section{Immunological staining}

Embryos were collected, fixed, and stained as described in Ma. haffey and Kaufman (1987), using the horseradish peroxidase (HRP) staining procedure, with the following substitution: In- stead of incubation with HRP-labeled secondary antibodies, embryos were incubated with biotin-labeled anti-rabbit secondary antibodies for $2 \mathrm{hr}$, washed for $1 \mathrm{hr}$, and then incubated with HRP-labeled avidin-biotin complex (Vector Labs) for $1 \mathrm{hr}$. Embryos were photographed using Nomarski optics, except for the embryo in Figure 7A, which was photographed using phasecontrast optics. To verify that the punctate pattern of $p b$ staining is nuclear, the $p b$ staining pattern was observed using FITC-labeled secondary antibodies, and this staining pattern was compared to the nuclear staining pattern observed by counterstaining the embryos with DAPI $(15 \mathrm{ng} / \mathrm{ml})$. In addition, the $p b$ staining is coincident with staining of other nuclear proteins, such as the engrailed and invected proteins (J. Mahaffey et al., in prep).

\section{Acknowledgments}

M.A.P. thanks Matt Scott and Amy Weiner for advice and encouragement in the early stages of this work and beyond. We thank F. Rudolf Turner for the scanning electron micrographs and for providing the sectioned material for in situ hybridization. Dave Leaf and Carol Ruppe provided assistance with raising antibodies, and Sandy Horikami provided the staged embryonic RNAs used in the developmental Northern blots. We are grateful to Allen Laughon, Matt Scott, Christine Rushlow, Michael Levine, Kim Fechtel, and James Fristrom for sharing unpublished information about the genes immediately proximal and distal to $p b$. We thank Christiane Nüsslein-Volhard for providing $D f(3 R) S C B^{X L 2}$ and $D f(3 R) L I N$. Bruce Baker, Tom Blumenthal, Dave Leaf, and Beth Raff provided helpful comments on earlier forms of the manuscript. Finally, we thank Dee Verostko for secretarial assistance. This work was supported by National Institutes of Health (NIH) grant GM-24299 to T.C.K.; M.A.P. was supported by a predoctoral NIH Genetics training grant and by a graduate fellowship from the Indiana University Institute for Molecular and Cellular Biology; R.J.D. was supported by a predoctoral NIH Molecular, Cellular, and Developmental training grant; D.L.C. was supported by an Indiana University Graduate Research and Development fellowship.

\section{References}

Abbott, M.K. 1984. "The relationship between the structure and function of the Antennapedia locus of Drosophila melanogaster." $\mathrm{PhD}$. dissertion, Indiana University Bloomington, Indiana.

Abbott, M.K. and T.C. Kaufman. 1986. The relationship between the functional complexity and the molecular organization of the Antennapedia locus of Drosophila melanogaster. Genetics 114: 919-942.

Akam, M. 1987. The molecular basis for metameric pattern in the Drosophila embryo. Development 101: 1-22.

Aviv, H. and P. Leder. 1972. Purification of biologically active globin messenger RNA by chromatography on oligothymidylic acid cellulose. Proc. Nat. Acad. Sci. 69: 1408-1412.

Beachy, P.A., S.L. Helfand, D.S. Hogness. 1985. Segmental distribution of bithorax complex proteins during Drosophila development. Nature 313: 545-551.

Beeman, R.W. 1987. A homeotic gene cluster in the red flour beetle. Nature 327: 247-249.

Bopp, D., M. Burri, S. Baumgartner, G. Frigerio, and M. Noll. 1986. Conservation of a large protein domain in the segmentation gene paired and in functionally related genes of Drosophila. Cell 47: 1033-1040. 
Bridges, C. and T. Dobzhansky. 1933. The mutant 'proboscipedia' in Drosophila melanogaster-- A case of hereditary homöosis. Wilhelm Roux's Arch Dev. Biol. 127: 575-590.

Carroll, S.B. and M.P. Scott. 1985. Localization of the fushi tarazu protein during Drosophila embryogenesis. Cell 43: $47-57$.

Carroll, S.B., R.A. Laymon, M.A. McCutcheon, P.D. Riley, and M.P. Scott. 1986. The localization and regulation of Antennapedia protein expression in Drosophila embryos. Cell 47: $113-122$.

Chadwick, R. and W. McGinnis. 1987. Temporal and spatial distribution of transcripts from the Deformed gene of Drosophila. EMBO I. 6: 779-789.

Chirgwin, J.M., A.E. Przybyla, R.J. MacDonald, and W.J. Rutter. 1979. Isolation of biologically active ribonucleic acid from sources enriched in ribonuclease. Biochemistry 18: 52945299.

Coleman, K., S.J. Poole, M.P. Weir, W.C. Soeller, and T. Kornberg. 1987. The invected gene of Drosophila: Sequence analysis and expression studies reveal a close kinship to the engrailed gene. Genes Dev. 1: 19-28.

Côté, S., A. Preiss, J. Haller, R. Schuh, A. Kienlin, E. Seifert, and $\mathrm{H}$. Jäckle. The gooseberry-zipper region of Drosophila: Five genes encode different spatially restricted transcripts in the embryo. EMBO I. 6: 2793-2801.

Denell, R.E. 1973. Homoeosis in Drosophila. Complementation studies with revertants of Nasobemia. Genetics 75: 279-297.

Denell, R.E., K.R. Hummels, B.T. Wakimoto, and T.C. Kaufman. 1981. Developmental studies of lethality associated with the Antennapedia gene complex in Drosophila melanogaster. Dev. Biol. 81: 43-50.

DiNardo, S., J.M. Kuner, J. Theis, and P.H. O'Farrell. 1985. Development of embryonic pattern in $D$. melanogaster as revealed by accumulation of the nuclear engrailed protein. Cell 43: 59-69.

Doyle, H., K. Harding, T. Hoey, and M. Levine. 1986. Transcripts encoded by a homoeo box gene are restricted to dorsal tissues of Drosophila embryos. Nature 323: 76-79.

Duncan, I.W. and T.C. Kaufman. 1975. Cytogenetic analysis of chromosome 3 in Drosophila melanogaster. Mapping of the proximal portion of the right arm. Genetics 80: 733-752.

Fechtel, K., J.E. Natzle, E.E. Brown, and J.W. Fristrom. 1988. Prepupal differentiation of Drosophila imaginal discs: Identification of four genes whose transcripts accumulate in response to a pulse of $20-$ Hydroxyecdysone. Genetics, (in press).

Feinberg, A.P. and B. Vogelstein. 1983. A technique for radiolabeling DNA restriction endonuclease fragments to high specific activity. Anal. Biochem. 132: 6-13.

Frigerio, G., M. Burri, D. Bopp, S. Baumgartner, and M. Nol. 1986. Structure of the segmentation gene paired and the Drosophila PRD gene set as part of a gene network. Cell 47: 735-746.

Frohnhöfer, H. and C. Nüsslein-Volhard. 1986. Organization of anterior pattern in the Drosophila embryo by the maternal gene bicoid. Nature 324: 120-125.

Gehring, W.J. and Y. Hiromi. 1986. Homeotic genes and the homeobox. Annu. Rev. Genet. 20: 147-173.

Guo. L.-H., P. Stephen, J.Y. Tso, R. Drousseau, S. Narang, D.Y. Thomas, and R. Wu. 1984. Synthesis of human insulin gene. VIII. Construction of expression vectors for fused proinsulin production in Escherichia coli. Gene 29: 251-254.

Hafen, E., A. Kuroiwa, and W. Gehring. 1984. Spatial distribution of transcripts from the segmentation gene fushi tarazu during Drosophila embryogenesis. Cell 37: 833-841.
Hartenstein, V. and J.A. Campos-Ortega. 1985. Fate-mapping in wild-type Drosophila melanogaster. I. The spatio-temporal pattern of embryonic cell divisions. Wilhelm Roux's Arch. Dev. Biol. 194: 181-195.

Haynie, J.L. and P.J. Bryant. 1986. Development of the eye-antenna imaginal disc and morphogenesis of the adult head in Drosophila melanogaster. J. Exper. Zool. 237: 293-308.

Hazelrigg, T. and T.C. Kaufman. 1983. Revertants of dominant mutations associated with the Antennapedia gene complex of Drosophila melanogaster. Genetics 105: 581-600.

Ingham, P.W., K.R. Howard, and D. Ish-Horowicz. 1985. Transcription pattern of the Drosophila segmentation gene hairy. Nature 318: 439-445.

Jürgens, G., R. Lehman, M. Schardin, and C. Nüsslein-Volhard. 1986. Segmental organisation of the head in the embryo of Drosophila melanogaster. Wilhelm Roux's Arch. Dev. Biol. 195: 359-377.

Kaufman, T.C. 1978. Cytogenetic analysis of chromosome 3 in Drosophila melanogaster. Isolation and characterization of four new alleles of the proboscipedia ( $p b)$ locus. Genetics 90: $579-596$.

Kaufman, T.C., R. Lewis, and B. Wakimoto. 1980. Cytogenetic analysis of chromosome 3 in Drosophila melanogaster. The homeotic gene complex in polytene interval 84A-B. Genetics 94: 115-133.

Kaufman, T.C. and G. Olsen. 1988. The homeotic genes of the Antennapedia gene complex of Drosophila melanogaster. Am. Nat. (in press).

Kuroiwa, A., U. Kloter, P. Baumgartner, and W.J. Gehring. 1985. Cloning of the homeotic Sex combs reduced gene in Drosophila and in situ localization of its transcripts. EMBO $/$. 4: 3757-3764.

Khandjian, E.W. 1987. Optimized hybridization of DNA blotted and fixed to nitrocellulose and nylon membranes. Biotechnology 5: 165-167.

Laughon, A., S.B. Carroll, F.A. Storfer, P.D. Riley, and M.P. Scott. 1985. Common properties of proteins encoded by Antennapedia complex genes of Drosophila melanogaster. Cold Spring Harbor Symp. Quant. Biol. 50: 253-262.

Leaf, D.S., J.A. Anstrom, J.E. Chin, M.A. Harkey, R.M. Showman, and R.A. Raff. 1987. Antibodies to a fusion protein identify a cDNA clone encoding msp130, a primary mesenchyme-specific cell surface protein of the sea urchin embryo. Dev. Biol. 121: 29-40.

Levine, M., E. Hafen, R. Garber, and W. Gehring. 1983. Spatial distribution of Antennapedia transcripts during Drosophila development. $E M B O$ I. 2: 2037-2046.

Levine, M., K. Harding, C. Wedeen, H. Doyle, T. Hoey, and H. Radomska. 1985. Expression of the homeo box gene family in Drosophila. Cold Spring Harbor Symp. Quant. Biol. 50: $209-222$.

Lewis, E.B. 1978. A gene complex controlling segmentation in Drosophila. Nature 276: 565-570.

Lewis, R., T. Hazelrigg, and G. Rubin. 1985. Effects of genomic positions on the expression of transduced copies of the white gene in Drosophila. Science 229: 558-561.

Lewis, R.A., T.C. Kaufman, R.E. Denell, and P. Tallerico. 1980a. Genetic analysis of the Antennapedia gene complex (ANT-C) and adjacent chromosomal regions of Drosophila melanogaster. I. Polytene chromosome segments 84B-D. Genetics 95: 367-381.

Lewis, R.A., B.T. Wakimoto, R.E. Denell, and T.C. Kaufman. 1980b. Genetic analysis of the Antennapedia gene complex (ANT-C) and adjacent chromosomal regions of Drosophila melanogaster. II. Polytene chromosome segments 84A-B. Genetics 95: 383-397. 
Lindsley, D.L. and E.M. Grell. 1968. Genetic variation of Drosophila melanogaster. Carnegie Inst. Washington Publ., No. 627.

Mahaffey, J. and T.C. Kaufman. 1987. Distribution of the Sex combs reduced gene products in Drosophila melanogaster. Genetics 117: 51-60.

Martinas-Arias, A. and P. Lawrence. 1985. Parasegments and compartments in the Drosophila embryo. Nature 313: 639642.

Martinez-Arias, A. 1986. The Antennapedia gene is required and expressed in parasegments 4 and 5 of the Drosophila embryo. $E M B O$ I. 5: 135-141.

Martinez-Arias, A., P. Ingham, M. Scott, and M. Akam. 1987. The spatial and temporal deployment of $D f d$ and Scr transcripts throughout development of Drosophila Development 100: 673-683.

McGinnis, W., R. Garber, J. Wirz, A. Kuroiwa, and W. Gehring. 1984a. A homologous protein-coding sequence in Drosophila homeotic genes and its conservation in other metazoans. Cell 37: 403-409.

McGinnis, W., M. Levine, E. Hafen, A. Kuroiwa, and W. Gehring. 1984b. A conserved DNA sequence found in homeotic genes of the Drosophila Antennapedia and bithorax complexes. Nature 308: 428-433.

Merrill, V., F.R. Turner, and T. Kaufman. 1987. A genetic and developmental analysis of mutations in the Deformed locus in Drosophila melanogaster. Dev. Biol. 122: 379-395.

O'Connell, P. and M. Rosbash. 1984. Sequence, structure, and codon preference of the Drosophila ribosomal protein 49 gene. Nucleic Acids Res. 12: 5495-5513.

Ouweneel, W.J. 1976. Developmental genetics of homeosis. Adv. Genet. 18: 179-248.

Poole, S.J., L.M. Kauvar, B. Drees, and T. Kornberg. 1985. The engrailed locus of Drosophila: Structural analysis of an embryonic transcript. Cell 40: 37-43.

Pultz, M.A. 1988. "A molecular and genetic analysis of proboscipedia and flanking genes in the Antennapedia Complex of Drosophila melanogaster." Ph.D. dissertation, Indiana University, Bloomington, Indiana.

Regulski, M., N. McGinnis, R. Chadwick, and W. McGinnis. 1987. Developmental and molecular analysis of Deformed; a homeotic gene controlling Drosophila head development. EMBO I. 6: 767-777.

Regulski, M., K. Harding, R. Kostriken, F. Karch, M. Levine, and W. McGinnis. 1985. Homeo box genes of the Antennapedia and bithorax complexes of Drosophila. Cell 43: 7180.

Riley, P.D., S.B. Carroll, and M.P. Scott. 1987. The expression and regulation of Sex combs reduced protein in Drosophila embryos. Genes Dev. 1: 716-730.

Rushlow, C., H. Doyle, T. Hoey, and M. Levine. 1987. Molecular characterization of the zerknüllt region of the Antennapedia gene complex in Drosophila. Genes Dev. 1: 12681279.

Sánchez-Herrero, E., I. Vernós, R. Marco, and G. Morata. 1985. Genetic organization of Drosophila bithorax complex. $\mathrm{Na}$ ture 313: 108-113.

Sato, T., P. Hayes, and R. Denell. 1985. Homoeosis in Drosophila: Roles and spatial patterns of expression of the Antennapedia and Sex combs reduced loci in embryogenesis. Dev. Biol. 111: 171-192.

Schneuwly, S. and W.J. Gehring. 1985. Homeotic transformation of thorax into head: Developmental analysis of a new Antennapedia allele in Drosophila melanogaster. Dev. Biol. 108: $377-386$.

Scott, M., A. Weiner, T. Hazelrigg, B. Polisky, V. Pirrotta, F.
Scalenghe, and T. Kaufman. 1983. The molecular organization of the Antennapedia locus of Drosophila. Cell 35: 763776.

Scott, M.P. and S.B. Carroll. 1987. The segmentation and homeotic gene network in early Drosophila development. Cell 51: $689-698$.

Scott, M.P. and A.J. Weiner. 1984. Structural relationships among genes that control development: Sequence homology between the Antennapedia, Ultrabithorax, and fushi tarazu loci of Drosophila. Proc. Natl. Acad. Sci. 71:41154119.

Spofford, J. 1976. Postion-effect variegation in Drosophila. In The genetics and biology of Drosophila lc, led. M. Ashburner and E. Novitski), pp. 955-1018 Academic Press, London.

Spradling, A.C. and A.P. Mahowald. 1979. Identification and genetic localization of mRNAs from ovarian follicle cells of Drosophila melanogaster. Cell 16: 589-598.

Stocker, R.F. 1982. Genetically displaced sensory neurons in the head of Drosophila project via different pathways into the same specific brain regions. Dev. Biol. 94: 31-40.

Struhl, G. 1981. A homeotic mutation transforming leg to antenna in Drosophila. Nature 292: 635-638.

. 1982. Genes controlling segmental specificatioin in the Drosophila thorax. Proc. Natl. Acad. Sci. 79: 7380-7384.

. 1983. Role of the $\mathrm{esc}^{+}$gene product in ensuring selective expression of segment-specific homeotic genes in Drosophila. J. Embryol. Exp. Morphol. 76: 297-331.

Turner, F.R. and A.P. Mahowald. 1979. Scanning electron microscopy of Drosophila embryogenesis. III. Formation of the head and caudal segments. Dev. Biol. 68: 96-109.

Villee, C. 1944. Phenogenetic studies of the homoeotic mutants of Drosophila melanogaster. II. The effects of temperature on the expression of proboscipedia. J. Exp. Zool. 96: 85102.

Wakimoto, B.T. and T.C. Kaufman. 1981. Analysis of larval segmentation in lethal genotypes associated with the Antennapedia gene complex in Drosophila melanogaster Dev. Biol. 81: $51-64$.

Wakimoto, B.T., F.R. Turner, and T.C. Kaufman. 1984. Defects in embryogenesis in mutants associated with the Antennapedia gene complex of Drosophila melanogaster. Dev. Biol. 102: $147-172$.

Wharton, K., B. Yedbovnick, V. Finnerty, and S. Artavanis-Tsakonas. 1985. opa: A novel family of transcribed repeats shared by the Notch locus and other developmentally regulated loci in D. melanogaster. Cell 40: 55-62.

White, R.A.H. and M. Wilcox. 1985. Protein products of the bithorax complex in Drosophila. Cell 39: 163-171.

Wirz, J., L.I. Fessler, and W.J. Gehring. 1986. Localization of the Antennapedia protein in Drosophila embryos and imaginal discs. $E M B O$ J. 5: 3327-3334. 


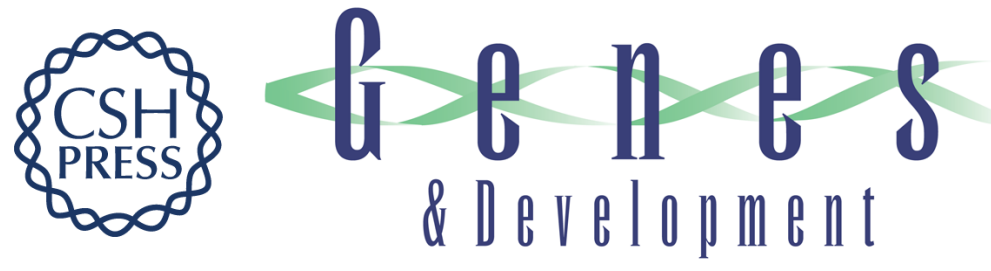

\section{The proboscipedia locus of the Antennapedia complex: a molecular and genetic analysis.}

M A Pultz, R J Diederich, D L Cribbs, et al.

Genes Dev. 1988, 2:

Access the most recent version at doi:10.1101/gad.2.7.901

References This article cites 72 articles, 18 of which can be accessed free at:

http://genesdev.cshlp.org/content/2/7/901.full.html\#ref-list-1

License

Email Alerting

Service

Receive free email alerts when new articles cite this article - sign up in the box at the top right corner of the article or click here.

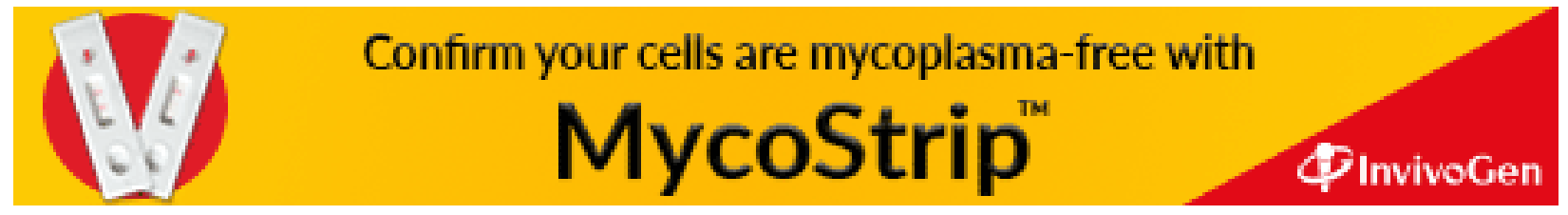

